\title{
20-Year Trends in Lipid Intake From Korean Adults: Using Korea National Dietary Survey Data
}

\author{
Yong-Seok Kwon \\ Rural Development Administration \\ Yu-Jin Hwang \\ Rural Development Administration \\ Hanna Chu \\ Rural Development Administration \\ Seyoung Ju ( $\nabla$ syoungju86@kku.ac.kr) \\ Konkuk University - Glocal Campus https://orcid.org/0000-0002-5655-9917
}

\section{Research}

Keywords: Lipid intake, Trend, KNHANES, Korea, 20-years

Posted Date: December 10th, 2020

DOI: https://doi.org/10.21203/rs.3.rs-124290/v1

License: () (1) This work is licensed under a Creative Commons Attribution 4.0 International License. Read Full License 


\section{Abstract}

Background: This study was undertaken to analyze 20-year trend regarding the lipid intake of Korean adults according to general characteristics, dietary behavior, food groups, and the Dietary Reference Intakes for Koreans (KDRIs), using KNHANES (Korea National Health and Nutrition Examination Survey) data.

Methods: This study selected adults who participated in the 24-hour recall method to investigate the trend of lipid intake for the 20 -year period from 1998 to 2018 of the KNHANES. A total of 86,222 individuals with adults aged 19 and over were included in the study.

Results: The lipid intake increased significantly in all individuals $(+7.34 \mathrm{~g})$, men $(+9.71 \mathrm{~g})$, and women $(+4.93 \mathrm{~g})(\mathrm{p}$ for trend<0.001) from the first to the seventh term. The lipid ratio contributed to energy increased significantly in all individuals $(+3.52 \%$ percentage points), men $(+3.12 \%$ percentage points), and women $(+3.90 \%$ percentage points) over the 20 -year period ( $p$ for trend $<0.001)$. Lipid intake increased significantly overall as well as by sex, age, residential area, education level (except below 12 years of education), and presence of obesity and abdominal obesity increased over the 20-year period. Total plant and animal lipid intake has increased over the 20-year period from 1998 to 2018 . Specifically, the ratio of lipid intake from potatoes, sugars, seeds and nuts, seaweed, beverages, meats, eggs, dairy products, and other animal foods has increased, while that from grains, beans, vegetables, mushrooms, fruits, vegetable oils, fish and shellfish, and animal fats has decreased.

Conclusions: The results of this study will aid in the preparation of basic data for nutrition policy and proper nutrition and dietary education with the aim of improving the diets of Koreans nationwide.

\section{Background}

Recently, nutritional imbalance caused by the development of the food industry and various dietary changes has emerged as an important problem. While the proportion of the population consuming excessive amounts of calories and fat has increased, the proportion with insufficient intake of vitamins and minerals, including calcium, iron, and riboflavin, remains high [1]. In addition, the prevalence of chronic diseases such as obesity, diabetes, and hypercholesterolemia, which are known to be closely related to diet, has been increasing steadily [2-4].

Lipids, which are composed of triglycerides, sterols, and fatty acids, play important roles as a component of cell membranes and an important source of energy and promote the absorption of fat-soluble vitamins [5]. Essential fatty acids ( $\mathrm{n}-6$ and n-3 fatty acids), which are important mediators of immune functions in the body, are taken in through foods [6]. Deficiency of essential fatty acids due to reduced lipid intake or malabsorption can cause dermatitis, weakened immune function, and delayed wound healing. Inhibited lipoprotein lipase activity, suppressed bile production and gallbladder obstruction, intestinal mucosal injury and short GI tract, gastrectomy and gastric hyperacidity, and cystic fibrosis can also lead to the development of lipid malabsorption [7]. In addition, fats play an important role in the taste of and preference for foods by affecting the texture and flavor of foods in cooking [8]. However, excessive intake of lipids can increase the risk of cerebrovascular and cardiovascular disorders, dyslipidemia, diabetes, hypertension, and obesity, because lipids provide more than twice the energy of carbohydrates and proteins [9].

Korean studies on fat intake include an evaluation of total fat and fatty acid intakes $[10,11]$ and trends of total fat and fatty acid intakes and chronic health conditions [12], while non-Korean studies include mainly fat intake, foods contributing to fat intake [13], intakes by fat type [14], and relationships between fat intake and chronic diseases $[15,16]$. Recently, specific diets have emerged as an important factor, with studies reporting that fat types and fat source foods, rather than total fat intake, are correlated with dyslipidemia and cardiovascular and cerebrovascular diseases. These diets include the Mediterranean diet, which includes vegetables, fruits, whole grains, low-fat dairy products, fish, and fowl [17-19].

Previous studies done on fat intake in Korea mainly focused on data analysis of the most recent 10 years and national data for short periods. Thus, this study was undertaken to analyze the fat intake of Korean adults according to general characteristics, dietary behavior, food groups, and the Dietary Reference Intakes for Koreans (KDRIs), using KNHANES (Korea National Health and Nutrition Examination Survey) data spanning the 20 years from 1998 to 2018 . The results of this study will aid in the preparation of basic data for nutrition policy and proper nutrition and dietary education with the aim of improving the diets of Koreans nationwide.

\section{Methods}

\section{Study design and survey data}

The KNHANES is a large-scale statistical survey conducted by extracting representative samples from the population of a whole nation to gain a comprehensive understanding of national health and nutrition and has been used as basic data for public health policies, such as policies on national nutrition improvement, disease prevention, and development of health promotion programs [20]. The sample survey plots were extracted every year: for November to December in 1998 (first term) and 2001 (second term), April to June in 2005 (third term), July to December in 2007 (fourth term, first half-year), and year-round since 2008 (fourth term, second half-year) [21]. Also, the KNHANES is composed of a health survey questionnaire, physical examination, and nutrition survey, among which the nutrition survey is composed of a diet survey, food frequency questionnaire, food intake survey using the 24-hour recall method, and food security survey, for the purpose of understanding the levels of food and nutrient intake and dietary habits of the Korean population [20].

\section{Study participants}

The study selected adults aged 19 and over who participated in the 24-hour recall method to investigate the trend of fat intake for the 20-year period from 1998 to 2018 of the KNHANES. Among them, individuals with abnormal data, such as less than 500 kcal or over 5,000 kcal total daily energy intake, and individuals taking health supplements were excluded (Fig. 1). And also, individuals who did not participate a nutrition survey including a food frequency 
questionnaire and a 24-hour dietary recall were excluded(missing data). A total of 86,222 individuals were included in the study: 7,404 in the first term (1998), 6,987 in the second term (2001), 6,433 in the third term (2005), 15,939 in the fourth term (2007-2009), 17,130 in the fifth term (2010-2012), 15,772 in the sixth term (2013-2015), and 16,557 in the seventh term (2016-2018). The KNHANES data used in this study were approved by the KCDC (Korea Centers for Disease Control and Prevention) Institutional Review Board (IRB) (approval numbers: 2007-02CON-04-P, 2008-04EXP-01-C, 2009-01CON-03-2C, 2010-02CON21-C, 2011-02CON-06-C, 2012-01EXP-01-2C, 2013-07CON-03-4C, 2013-12EXP-03-5C, and 2018-01-03-P-A). Among these, the 2015-2017 KNHANES survey was conducted without the deliberation of the IRB, because studies were to be conducted directly by the government for public welfare, according to Article 2 , Subparagraph 1, of the Bioethics and Safety Act and Article 2, Paragraph 2, Subparagraph 1, of the Enforcement Regulations of the same Act. However, the IRB deliberation has been reopened for the collection of human materials and provision of raw data to third parties since 2018 [1].

\section{Lipid intake}

The lipid intake data used in the study were the lidid intake (variable name: Nf_fat) data listed in the 24-hour recall survey. Various fatty acid data used in previous studies to analyze lipid intake trends of adults and adolescents [10,12, 22] were not included for the first term (1998) to fifth term (2010-2012). As in the study by Song \& Shim [10], the same codes have been used for the same foods since the fatty acid data of the fourth term (2007-2009) and sixth term (2013 2015) can be merged through food code matching. However, the trends for the 20 -year period cannot be analyzed because the food codes were different from the first term (1998) to the third term (2005), and for substitutional foods, in particular, it is almost impossible to combine the fatty acid data. Therefore, in this study, the analysis was performed using lipid intake data from diets.

\section{General characteristics}

General characteristics of the individuals were analyzed using sex, age, education level, residential area, and household income. For sex, residential area, and household income, the basic variables included in the KNHANES raw data were used as is, while for education level, job status (occupation), marital status, and age, properly modified data were used for the study on the basis of the health survey questionnaire. First, for education level, "elementary school graduate" and "middle school graduate" were combined into "below high school graduate," which was used along with "high school graduate" and "college and higher." Marital status was divided into unmarried and married; residential area, into urban area and rural (eup/myeon) area; and job status, into worker (employed) and non-worker (unemployed). The prevalence of obesity was determined using BMI variables, with a value of less than $18.5 \mathrm{~kg} / \mathrm{m} 2 \mathrm{being}$ designated as underweight; between $18.5 \mathrm{~kg} / \mathrm{m} 2$ and $23.0 \mathrm{~kg} / \mathrm{m} 2$, as normal weight; between $23.0 \mathrm{~kg} / \mathrm{m} 2$ and $25.0 \mathrm{~kg} / \mathrm{m} 2$, as overweight; and over $25.0 \mathrm{~kg} / \mathrm{m} 2$, as obese, on the basis of the WHO Asia-Pacific guidelines. Abdominal obesity was defined as a waist circumference of over $90 \mathrm{~cm}$ in men and over $85 \mathrm{~cm}$ in women, and all others were defined as the normal group, according to the criteria of the Korean Society for the Study of Obesity [23]. The individuals were divided into age groups of $19-29,30-49,50-64,65-74$, and over 75 years old.

\section{Dietary behavior}

Dietary behavior was analyzed in terms of meals, meals by cooking location, number of times eating out, and level of food security. Meals (variable name: n_meal) were divided into breakfast, lunch, and dinner, and the eating of each meal was analyzed. For snacks, individuals who selected snacks (variable value: 4) from the variables for meals were classified as taking snacks, and all other individuals were classified as taking no snacks. Cooking location, similar to the classification used in the study of Chung et al. [24], was classified using the eating-out variables (variable name: n_mtype) of: homemade meals (prepared at home, packed lunch prepared at home, prepared at neighbor's or relative's home), commercial food services (Korean foods, western foods, Chinese foods, Japanese foods, snack foods, bakery, street stand/store, box lunch, instant foods such as ramen, fast foods, convenience store foods, and other types of eating out), and institutional food services (school meal service, workplace meal service, preschool/kindergarten meal service, senior-center meal service, free meal service, temple/religion-related meal service, and other meal service). The number of times eating out (variable name: L_OUT_FQ) used questionnaire items of the dietary survey after modification. "Once a day" and "more than twice a day" were combined into "more than once a day," while "1-2 times a week," "3-4 times a week," and "5-6 times a week" were combined into "1-6 times a week," and "1-3 times a month" and "less than once a month" were used without modification. The level of food security was classified on the basis of previous studies using the question "Which best describes the diet of your household for the past year?", which has been used as a question on the dietary survey since the third term $(2005)$ of the KNHANES [25, 26]. The level of food security was classified and used for analysis as follows. Those who answered "Everyone in our family has enough food and a sufficient variety of food and can eat as much as we want" as "sufficiently food secure"; "Everyone in our family has enough food, but we can't eat a wide variety of food," as "mildly food insecure"; "We have sometimes had insufficient amounts of food to eat due to economic difficulties," as moderately food insecure"; and "We have often had insufficient amounts of food to eat due to economic difficulties," as "severely food insecure."

\section{Food group classification}

Individual 24-hour recall food intake survey data was used to analyze lipid intake by food group, and the food group classification used the animal/plant foods presented in the KNHANES and Reprocessed Food Group Classification 2 (variable name: N_Kindg in 1998 and 2001 and N_Kindg2 after 2001 ) variables. The final classifications were: 1) grains and their products, 2) potatoes and starches, 3) sugars and their products, 4) beans and their products, 5) seeds and nuts and their products, 6) vegetables, 7) mushrooms, 8) fruits, 9) vegetable oils, 10) seaweed, 11) beverages and liquors, 12) seasonings, 13) other plant foods, 14) meats and their products, 15) eggs, 16) fish and shellfish, 17) milk and dairy products, 18) animal fats, and 19) other animal foods.

Statistical analysis

All analyses were performed using SAS (Statistical Analysis System, SAS Institute, Cary, NC, USA) Version 9.4, and statistical significance was tested at a = 0.05. Because the KNHANES data were collected using multistage stratified cluster sampling, the analysis was performed in consideration of the stratification variable (Strata: Kstrata), clustering variable (Cluster: PSU (primary sampling unit)), and weight (Wt_ntr_t (time series weight) was used for the 1998, 2001, and 2005 data, and Wt_ntr was used for other years). Categorical variables such as the general characteristics and dietary behavior of the individuals in each year were expressed as frequency (n) and weighted percentages using frequency analysis, and the significance was tested using the chi-squared test. Continuous 
variables such as lipid intake and food intake were expressed as mean and standard error using descriptive analysis. For the significance of lipid intake and food intake by year, the $p$ for trend values was obtained using PROC SURVEYREG. At this time, prior to the analysis, the lipid intake by sex was adjusted using age and energy intake, and the lipid intake by age was adjusted using sex and energy intake. The lipid intake and food intake were adjusted using sex, age, and energy intake.

\section{Results}

\section{Trends of energy and lipid intake by year and lipid ratio contributed to energy}

The results of the trends of each year's energy intake, lipid intake, and lipid ratio contributed to energy for all individuals and sex are presented in Fig. 2. The energy intake did not vary significantly among all individuals from the first term (1998) to the seventh term (2016-2018). It increased significantly ( $p$ for trend $<0.001)$ in men, while decreasing significantly ( $\mathrm{p}$ for trend $<0.001)$ in women. The lipid intake increased significantly in all individuals $(+7.34 \mathrm{~g})$, men $(+$ $9.71 \mathrm{~g})$, and women $(+4.93 \mathrm{~g})$ ( $\mathrm{p}$ for trend $<0.001)$ from the first to the seventh term. The lipid ratio contributed to energy increased significantly in all individuals ( $+3.52 \%$ percentage points), men $(+3.12 \%$ percentage points), and women $(+3.90 \%$ percentage points) over the 20 -year period ( $p$ for trend $<$ 0.001).

\section{General characteristics of individuals}

The general characteristics of the individuals are shown in Table 1. There was no significant difference in sex, with the proportion of men ranging from 49.2$49.6 \%$ and that of women from $50.4-51.0 \%$ over the 20 -year period. By age, the proportion of individuals under 49 years old decreased, and that over 50 years old increased (50 to 64 years old: 9.5 percentage points increase, 65 to 74 years old: 3.2 percentage points increase, over 75 years old: 3.9 percentage points increase) $(p<0.001)$. The average age also increased $(p<0.001)$. By residential area, the proportion of urban residents increased in all years by about $7.3 \% p$ (percentage points), rising from $77.5 \%$ in the first term to $84.8 \%$ in the seventh, while the proportion of rural residents decreased by about $7.3 \% \mathrm{p}$ (percentage points), falling from $22.5 \%$ in the first term to $15.2 \%$ in the seventh term $(p<0.034)$. Marital status showed that the proportion of married individuals was significantly higher than unmarried individuals in all years $(p<0.001)$. The household income level of the "low" group decreased by $2.9 \% p(p e r c e n t a g e ~ p o i n t s)$ from the first to seventh term. On the other hand, the household income level of the "high" group increased by about $3 \% \mathrm{p}$ (percentage points), rising from $28.5 \%$ in the first term to $31.5 \%$ in the seventh term $(p<0.001)$. For work status, there was a significantly higher proportion of workers compared to nonworkers in all years $(p<0.001)$. In terms of education level, the group with less than 12 years of education (below middle school graduate) decreased by $12.8 \% \mathrm{p}$ (percentage points) from the first to seventh term, while the group with more than 12 years of education (above college graduate) increased by about $25.3 \% p$ (percentage points) over the same period $(p<0.001)$. In terms of the presence of obesity, the normal group decreased by about $8.0 \% p$, while the obese group increased by about $9.3 \% \mathrm{p}$ (percentage points) over the 20 -year period $(\mathrm{p}<0.001)$. Average BMI rose significantly by about $0.86 \mathrm{~kg} / \mathrm{m} 2$, from $23.09 \mathrm{~kg} / \mathrm{m} 2$ in the first term to $23.95 \mathrm{~kg} / \mathrm{m} 2$ in the seventh term $(\mathrm{p}<0.001)$. Regarding the presence of abdominal obesity, the obese group increased significantly by about $8 \%$ p (percentage points), from $20.58 \%$ in the first term to $28.56 \%$ in the seventh $(p<0.001)$. Waist circumference increased significantly by about $2.42 \mathrm{~cm}$, from $79.84 \mathrm{~cm}$ in the first term to $82.26 \mathrm{~cm}$ in the seventh $(p<0.001)$. 
Table 1

General characteristics of subject samples (1998 2018)

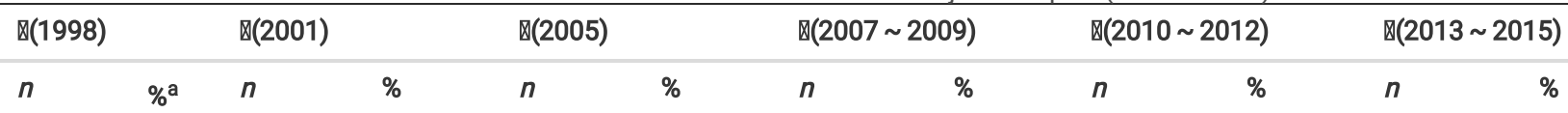

\section{Gender}

Male

$3434 \quad 49.2 \quad 3204$

$49.3 \quad 2867$

49.3

Female

$3970 \quad 50.8 \quad 3783$

$\begin{array}{lll}50.7 & 3566 & 50.7\end{array}$

6488

49.3

6987

50.7

Age

$19 \sim 2$

1527

$26.6 \quad 1352$

$25.6 \quad 1030$

22.2

9451

10143

49.0

$\begin{array}{ll}6554 & 49.2 \\ 9218 & 50.8\end{array}$

$30 \sim 49$

$3294 \quad 45.8 \quad 3356$

$45.9 \quad 2973$

$50 \sim 64$

$\begin{array}{lll}1631 & 18.1 & 1383\end{array}$

$18.2 \quad 1439$

46.0

1995

20.1

\begin{tabular}{|llll}
\hline 1871 & 18.9 & 1832 & 18.0 \\
\hline 6060 & 42.5 & 5354 & 40.1 \\
\hline 4797 & 24.1 & 4392 & 26.1 \\
\hline 2853 & 8.9 & 2580 & 9.3 \\
\hline 1549 & 5.6 & 1614 & 6.5 \\
\hline 45.6 & 0.2 & 46.5 & 0.2 \\
\hline
\end{tabular}

$65 \sim 74$
$75+$

Average
(Mean, SE)

\section{Residential}

area

\begin{tabular}{|c|c|c|c|c|c|c|c|c|c|c|c|c|}
\hline Urban & 4572 & 77.5 & 5415 & 80.3 & 5077 & 81.6 & 11586 & 80.8 & 13439 & 79.8 & 12586 & 82.0 \\
\hline Rural area & 2832 & 22.5 & 1572 & 19.7 & 1356 & 18.4 & 4353 & 19.2 & 3691 & 20.2 & 3186 & 18.0 \\
\hline \multicolumn{13}{|l|}{ Marital status } \\
\hline Unmarried & 1186 & 20.8 & 1172 & 22.2 & 1049 & 22.4 & 1923 & 19.4 & 2194 & 21.7 & 2300 & 21.6 \\
\hline Married & 6218 & 79.2 & 5814 & 77.8 & 5377 & 77.6 & 13635 & 80.6 & 14893 & 78.3 & 13459 & 78.4 \\
\hline \multicolumn{13}{|l|}{$\begin{array}{l}\text { Household } \\
\text { income }\end{array}$} \\
\hline Low & 1661 & 18.7 & 1414 & 21.5 & 1391 & 19.3 & 3363 & 16.2 & 3472 & 16.3 & 3206 & 15.8 \\
\hline Middle-low & 1728 & 21.9 & 1626 & 25.3 & 1620 & 26.0 & 3879 & 25.2 & 4380 & 27.2 & 3982 & 24.9 \\
\hline Middle-high & 2128 & 30.8 & 1633 & 25.8 & 1713 & 28.2 & 4094 & 28.7 & 4543 & 29.3 & 4174 & 29.0 \\
\hline High & 1887 & 28.5 & 1909 & 27.5 & 1647 & 26.5 & 4167 & 29.9 & 4501 & 27.2 & 4319 & 30.4 \\
\hline \multicolumn{13}{|l|}{ Occupation } \\
\hline Unemployed & 4556 & 59.8 & 4078 & 59.3 & 3878 & 61.0 & 8379 & 60.0 & 8924 & 63.6 & 7753 & 62.2 \\
\hline Employed & 2848 & 40.2 & 2907 & 40.7 & 2550 & 39.0 & 6429 & 40.0 & 6667 & 36.4 & 5807 & 37.8 \\
\hline \multicolumn{13}{|l|}{$\begin{array}{l}\text { Educational } \\
\text { Level }\end{array}$} \\
\hline$<12$ years & 3184 & 34.4 & 2356 & 31.3 & 2194 & 28.9 & 6026 & 29.6 & 5703 & 27.5 & 4541 & 24.4 \\
\hline 12 year & 2581 & 39.2 & 2489 & 37.6 & 2207 & 35.4 & 4296 & 31.6 & 4328 & 29.9 & 3758 & 28.9 \\
\hline$\geqq 12$ years & 1639 & 26.4 & 2134 & 31.2 & 2029 & 35.7 & 4550 & 38.8 & 5559 & 42.5 & 5250 & 46.8 \\
\hline \multicolumn{13}{|l|}{$\begin{array}{l}\text { Obesity } \\
\text { status }^{d}\end{array}$} \\
\hline Underweight & 360 & 5.5 & 286 & 5.3 & 207 & 4.6 & 704 & 4.8 & 754 & 4.9 & 619 & 4.4 \\
\hline Normal & 3021 & 46.9 & 2356 & 42.1 & 1856 & 39.3 & 5946 & 39.9 & 6538 & 40.5 & 5853 & 39.9 \\
\hline Overweight & 1465 & 22.0 & 1356 & 23.2 & 1202 & 24.7 & 3579 & 23.9 & 3738 & 22.6 & 3476 & 22.9 \\
\hline Obesity & 1754 & 25.6 & 1716 & 29.4 & 1518 & 31.5 & 4678 & 31.4 & 5040 & 32.0 & 4882 & 32.8 \\
\hline
\end{tabular}

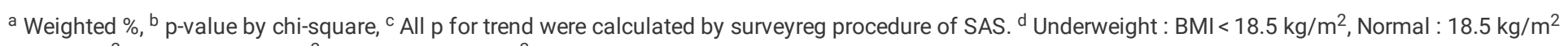

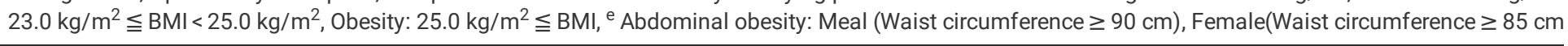




\begin{tabular}{|c|c|c|c|c|c|c|c|c|c|c|c|c|c|}
\hline & \multicolumn{2}{|c|}{ 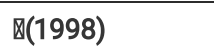 } & \multicolumn{2}{|c|}{$\mathbb{Q ( 2 0 0 1 )}$} & \multicolumn{2}{|c|}{ 区(2005) } & \multicolumn{2}{|c|}{$\Phi(2007 \sim 2009)$} & \multicolumn{2}{|c|}{$\rrbracket(2010 \sim 2012)$} & \multicolumn{2}{|c|}{$\rrbracket(2013 \sim 2015)$} & \\
\hline & $n$ & $\%^{a}$ & $n$ & $\%$ & $n$ & $\%$ & $n$ & $\%$ & $n$ & $\%$ & $n$ & $\%$ & \\
\hline $\mathrm{BMI}\left(\mathrm{kg} / \mathrm{m}^{2}\right)$ & 23.09 & 0.05 & 23.40 & 0.05 & 23.62 & 0.06 & 23.61 & 0.04 & 23.65 & 0.04 & 23.77 & 0.04 & \\
\hline \multicolumn{14}{|c|}{$\begin{array}{l}\text { Abdominal obesity } \\
\text { status }\end{array}$} \\
\hline Normal & 5119 & 79.42 & 4312 & 76.49 & 3589 & 75.99 & 10739 & 74.93 & 11828 & 75.54 & 10864 & 75.13 & \\
\hline $\begin{array}{l}\text { Abdominal } \\
\text { obesity }\end{array}$ & 1481 & 20.58 & 1398 & 23.51 & 1196 & 24.01 & 4157 & 25.07 & 4219 & 24.46 & 3965 & 24.87 & \\
\hline $\begin{array}{l}\text { Waist } \\
\text { circumference } \\
(\mathrm{cm})\end{array}$ & 79.84 & 0.16 & 80.72 & 0.17 & 80.64 & 0.17 & 81.19 & 0.14 & 80.92 & 0.14 & 81.34 & 0.13 & $\varepsilon$ \\
\hline
\end{tabular}

${ }^{a}$ Weighted \%, b p-value by chi-square, ${ }^{c}$ All p for trend were calculated by surveyreg procedure of SAS. ${ }^{\mathrm{d}}$ Underweight : BMl $<18.5 \mathrm{~kg} / \mathrm{m}^{2}, \mathrm{Normal}: 18.5 \mathrm{~kg} / \mathrm{m}^{2}$ $23.0 \mathrm{~kg} / \mathrm{m}^{2} \leqq \mathrm{BMI}<25.0 \mathrm{~kg} / \mathrm{m}^{2}$, Obesity: $25.0 \mathrm{~kg} / \mathrm{m}^{2} \leqq \mathrm{BMl},{ }^{\mathrm{e}}$ Abdominal obesity: Meal (Waist circumference $\left.\geq 90 \mathrm{~cm}\right)$, Female(Waist circumference $\geq 85 \mathrm{~cm}$

\section{Lipid intake in each year by general characteristics}

The results of lipid intake in each year by general characteristics are shown in Table 2. Lipid intake increased significantly overall as well as by sex, age, residential area, education level (except below 12 years of education), and presence of obesity and abdominal obesity over the 20-year period, regardless of adjustment (sex, age, and energy intake) (Unadjusted $\mathrm{p}$ for trend $<0.05$, Adjusted for trend $<0.001$ ). However, in the case of education level, the group with less than 12 years of education (below middle school graduate) showed changes in lipid intake (24.04-30.15 g/day) from the first to seventh terms, but the difference was not significant when not adjusted. When it was adjusted using sex, age, and energy intake, the lipid intake increased ( $p$ for trend $<0.001)$. 
Table 2

Trends of Lipid intake by General characteristics

\begin{tabular}{|c|c|c|c|c|c|c|c|c|c|c|c|c|c|c|c|}
\hline \multirow[t]{2}{*}{$\begin{array}{l}\text { Intake, } \\
\text { g/day }\end{array}$} & \multicolumn{2}{|c|}{$凶(1998)$} & \multicolumn{2}{|c|}{$\rrbracket(2001)$} & \multicolumn{2}{|c|}{$凶(2005)$} & \multicolumn{2}{|c|}{$\mathbb{8}(2007 \sim 2009)$} & \multicolumn{2}{|c|}{$\begin{array}{l}\text { ब(2010 } \\
2012)\end{array}$} & \multicolumn{2}{|c|}{$\begin{array}{l}\bigotimes(2013 \sim \\
2015)\end{array}$} & \multicolumn{2}{|c|}{$\rrbracket(2016 \sim 2018)$} & \multirow{2}{*}{$\begin{array}{l}\text { Un } \\
\text { p-t }\end{array}$} \\
\hline & Mean & SE & Mean & SE & Mean & SE & Mean & SE & Mean & SE & Mean & SE & Mean & SE & \\
\hline Total & 38.80 & 0.63 & 39.87 & 0.62 & 43.16 & 0.58 & 37.91 & 0.37 & 42.92 & 0.41 & 45.28 & 0.39 & 46.14 & 0.40 & $<0$ \\
\hline \multicolumn{16}{|l|}{ Sex } \\
\hline Male & 44.06 & 0.83 & 45.38 & 0.86 & 49.54 & 0.78 & 45.31 & 0.57 & 51.06 & 0.59 & 52.29 & 0.56 & 53.77 & 0.56 & $<0$ \\
\hline Female & 33.70 & 0.59 & 34.51 & 0.61 & 36.96 & 0.59 & 30.71 & 0.34 & 35.10 & 0.41 & 38.49 & 0.39 & 38.63 & 0.38 & $<0$ \\
\hline \multicolumn{16}{|l|}{ Age } \\
\hline $19 \sim 29$ & 47.26 & 1.18 & 46.71 & 1.12 & 53.12 & 1.18 & 48.93 & 0.91 & 57.30 & 1.08 & 59.78 & 0.91 & 59.84 & 1.10 & $<0$ \\
\hline $30 \sim 49$ & 41.37 & 0.76 & 43.79 & 0.82 & 46.95 & 0.80 & 41.86 & 0.49 & 47.99 & 0.56 & 51.18 & 0.54 & 52.87 & 0.60 & $<0$ \\
\hline $50 \sim 64$ & 29.42 & 0.79 & 30.70 & 0.82 & 34.78 & 0.80 & 30.70 & 0.48 & 35.20 & 0.48 & 38.89 & 0.56 & 39.91 & 0.51 & $<0$ \\
\hline $65 \sim 74$ & 21.13 & 0.83 & 23.57 & 1.27 & 25.31 & 0.89 & 21.55 & 0.49 & 24.71 & 0.47 & 27.47 & 0.56 & 30.22 & 0.55 & $<0$ \\
\hline $75+$ & 19.39 & 1.27 & 17.39 & 1.04 & 21.53 & 1.41 & 17.05 & 0.59 & 18.26 & 0.49 & 19.62 & 0.49 & 22.28 & 0.53 & $<0$ \\
\hline \multicolumn{16}{|c|}{ Residential area } \\
\hline Urban & 40.96 & 0.72 & 41.83 & 0.71 & 44.82 & 0.67 & 39.24 & 0.42 & 44.36 & 0.45 & 46.22 & 0.44 & 47.21 & 0.43 & $<0$ \\
\hline Rural area & 31.35 & 1.28 & 31.87 & 1.34 & 35.83 & 1.24 & 32.33 & 0.85 & 37.23 & 1.10 & 40.99 & 1.03 & 40.15 & 1.14 & $<0$ \\
\hline \multicolumn{16}{|l|}{$\begin{array}{l}\text { Marital } \\
\text { status }\end{array}$} \\
\hline Unmarried & 36.98 & 0.62 & 38.43 & 0.67 & 40.50 & 0.61 & 35.07 & 0.37 & 39.23 & 0.40 & 41.87 & 0.41 & 42.54 & 0.41 & $<0$ \\
\hline Married & 45.72 & 1.31 & 44.92 & 1.23 & 52.39 & 1.12 & 48.90 & 0.97 & 56.24 & 1.00 & 57.62 & 0.85 & 58.26 & 0.95 & $<0$ \\
\hline \multicolumn{16}{|c|}{ Household Income } \\
\hline Low & 29.29 & 1.00 & 31.55 & 1.16 & 32.44 & 1.08 & 27.87 & 0.81 & 30.10 & 0.79 & 29.44 & 0.72 & 32.70 & 0.89 & $0 . \mathrm{C}$ \\
\hline Middle-low & 35.27 & 0.96 & 38.70 & 1.04 & 43.78 & 1.04 & 36.89 & 0.69 & 42.39 & 0.74 & 43.58 & 0.64 & 44.45 & 0.74 & $<0$ \\
\hline Middle-high & 41.12 & 1.01 & 42.57 & 1.05 & 45.96 & 0.94 & 40.39 & 0.61 & 46.93 & 0.72 & 48.77 & 0.66 & 49.33 & 0.65 & $<0$ \\
\hline High & 45.24 & 0.93 & 45.52 & 1.05 & 47.57 & 0.95 & 42.21 & 0.60 & 46.79 & 0.66 & 51.75 & 0.68 & 51.42 & 0.68 & $<0$ \\
\hline \multicolumn{16}{|l|}{ Occupation } \\
\hline Employed & 40.50 & 0.72 & 43.08 & 0.79 & 46.18 & 0.69 & 40.86 & 0.45 & 45.89 & 0.53 & 48.74 & 0.49 & 49.52 & 0.51 & $<0$ \\
\hline Unemployed & 36.26 & 0.79 & 35.20 & 0.83 & 38.46 & 0.78 & 32.34 & 0.52 & 37.32 & 0.59 & 39.12 & 0.58 & 40.12 & 0.59 & $<0$ \\
\hline \multicolumn{16}{|c|}{ Educational Level } \\
\hline$<12$ years & 27.47 & 0.56 & 27.91 & 0.70 & 30.15 & 0.68 & 24.04 & 0.40 & 26.39 & 0.45 & 27.48 & 0.46 & 27.32 & 0.45 & 0.5 \\
\hline
\end{tabular}

${ }^{a}$ All p for trend were calculated by surveyreg procedure of SAS. ${ }^{b}$ Total and all variables (excluding sex and age) were adjusted for sex, age and energy intak $\epsilon$ for age and energy intake. ${ }^{d}$ Categorical age was adjusted for sex and energy intake. 


\begin{tabular}{|c|c|c|c|c|c|c|c|c|c|c|c|c|c|c|c|c|}
\hline \multirow[t]{2}{*}{$\begin{array}{l}\text { Intake, } \\
\text { g/day }\end{array}$} & \multicolumn{2}{|c|}{$\bigotimes(1998)$} & \multicolumn{2}{|c|}{$\rrbracket(2001)$} & \multicolumn{2}{|c|}{$\llbracket(2005)$} & \multicolumn{3}{|c|}{$\rrbracket(2007 \sim 2009)$} & \multicolumn{2}{|c|}{$\begin{array}{l}\otimes(2010 \sim \\
2012)\end{array}$} & \multicolumn{2}{|c|}{$\begin{array}{l}\mathbb{Q}(2013 \sim \\
2015)\end{array}$} & \multicolumn{2}{|c|}{$\rrbracket(2016 \sim 2018)$} & \multirow{2}{*}{$\begin{array}{l}\text { Un } \\
\text { p-t }\end{array}$} \\
\hline & Mean & SE & Mean & SE & Mean & SE & Mea & & SE & Mean & SE & Mean & SE & Mean & SE & \\
\hline 12 year & 42.16 & 0.86 & 42.16 & 0.80 & 45.21 & 0.81 & 38.5 & & 0.55 & 43.08 & 0.64 & 44.29 & 0.59 & 43.82 & 0.58 & $0 . C$ \\
\hline$\geqq 12$ years & 48.59 & 1.00 & 49.03 & 0.93 & 51.67 & 0.98 & 46.7 & & 0.59 & 53.16 & 0.62 & 54.82 & 0.60 & 55.11 & 0.57 & $<0$ \\
\hline \multicolumn{17}{|c|}{ Obesity status } \\
\hline Underweight & 35.78 & 1.98 & 39.48 & 2.02 & 42.09 & 2.74 & 37.5 & & 1.36 & 43.70 & 1.40 & 44.76 & 1.50 & 46.07 & 1.57 & $<0$ \\
\hline Normal & 39.36 & 0.79 & 39.20 & 0.73 & 42.81 & 0.93 & 37.2 & & 0.53 & 41.87 & 0.55 & 45.25 & 0.55 & 45.18 & 0.54 & $<0$ \\
\hline Overweight & 38.88 & 0.94 & 39.00 & 1.00 & 41.70 & 1.04 & 37.9 & & 0.66 & 42.03 & 0.77 & 44.37 & 0.67 & 45.33 & 0.69 & $<0$ \\
\hline Obesity & 36.69 & 0.91 & 38.83 & 1.09 & 42.83 & 0.98 & 37.1 & & 0.56 & 43.82 & 0.69 & 45.07 & 0.67 & 47.25 & 0.65 & $<0$ \\
\hline \multicolumn{17}{|c|}{ Abdominal obesity status } \\
\hline Normal & 39.38 & 0.69 & 39.98 & 0.65 & 43.48 & 0.70 & 38.31 & 0.42 & & 43.41 & 0.45 & 45.91 & 0.43 & 46.14 & 0.43 & $<0$ \\
\hline $\begin{array}{l}\text { Abdominal } \\
\text { obesity }\end{array}$ & 34.50 & 0.95 & 36.08 & 1.09 & 39.41 & 1.09 & 34.72 & 0.59 & & 40.31 & 0.77 & 42.08 & 0.75 & 45.33 & 0.70 & $<0$ \\
\hline
\end{tabular}

a All p for trend were calculated by surveyreg procedure of SAS. ${ }^{b}$ Total and all variables (excluding sex and age) were adjusted for sex, age and energy intak $\epsilon$ for age and energy intake. ${ }^{d}$ Categorical age was adjusted for sex and energy intake.

Dietary behavior by survey year and lipid intake by dietary behavior

The results of dietary behavior by survey year are shown in Supplementary Table 1. For breakfast, the proportion of those who skipped the meal increased significantly by $14.2 \% \mathrm{p}$ (percentage points), nearly doubling the ratio, from $11.8 \%$ in the first term to $26.0 \%$ in the seventh term ( $p<0.001$ ). For lunch and dinner, the proportion of those who ate both meals was over $90 \%$ in all years. The proportion of those who ate snacks increased by about $21.0 \% \mathrm{p}$ (percentage points), rising from $72.3 \%$ in the first term to $93.3 \%$ in the seventh term $(p<0.001)$. In terms of cooking location, homemade meals declined by about $16 \% p$ (percentage points) over the 20 -year period, falling from $95.9 \%$ in the first term to $79.5 \%$ in the seventh term $(p<0.001)$. On the other hand, eating out rose by about $33.9 \%$ p (percentage points), from $64.0 \%$ in the first term to $97.9 \%$ in the seventh $(p<0.001)$. And the proportion of people using food service facilities ranged from $82.6-87.3 \%$. In terms of the number of times subjects ate out, the proportion of those who ate out more than once a week rose by about $21.1 \% \mathrm{p}$ (percentage points), from $22.6 \%$ in the first term to $43.7 \%$ in the third term, and then decreased to around $25.5-28.6 \%$ from the fourth term onward, which is slightly higher than in the first term but much lower than in the third term $(p<0.001)$. By level of food security, the proportion of the "sufficiently food secure" group increased by $22.4 \%$ p (percentage points), from $33.8 \%$ in the third term, when the survey was conducted for the first time, to $56.2 \%$ in the seventh term ( $p$ $<0.001)$.

The lipid intakes by dietary behavior are shown in Table 3. For daily meals, breakfast decreased significantly by about $1.13 \mathrm{~g}$, from $7.61 \mathrm{~g}$ in the first term to $6.49 \mathrm{~g}$ in the seventh term (Unadjusted $\mathrm{p}$ for trend $<0.001$, Adjusted $\mathrm{p}$ for trend $<0.001$ ). On the other hand, lunch, dinner, and snacks all increased from the first to seventh term (Unadjusted $p$ for trend $<0.001$, Adjusted $p$ for trend $<0.001$ ). Regarding cooking location, lipid intake from meals prepared at home fell significantly over the 20-year period (Unadjusted $p$ for trend $<0.001$, Adjusted $p$ for trend $<0.001$ ), while lipid intake from meals provided by commercial food services rose significantly (Unadjusted $p$ for trend $<0.001$, Adjusted $p$ for trend $<0.001$ ). The number of times eating out per week showed that lipid intake for the group that ate out more than once a day and one to six times a week increased over the 20-year period (Unadjusted $p$ for trend $<0.001$, Adjusted $p$ for trend $<0.001$ ), while lipid intake for the group that ate out one to three times a month showed no significant change when not adjusted, and that for the group that almost never ate out decreased significantly when not adjusted (Unadjusted p for trend $<0.001$ ). When adjusted by sex, age, and energy intake, however, lipid intake increased significantly (Adjusted p for trend < 0.001). Finally, lipid intake by level of food security showed that the "enough food secure," "mildly food insecure," and "moderately food insecure" groups all increased significantly even when not adjusted (Unadjusted p for trend $<0.05$ ) and also when adjusted by sex, age, and energy intake (Adjusted $p$ for trend $<0.001$ ). 
Table 3

Trends of Lipid intake by Dietary behavior.

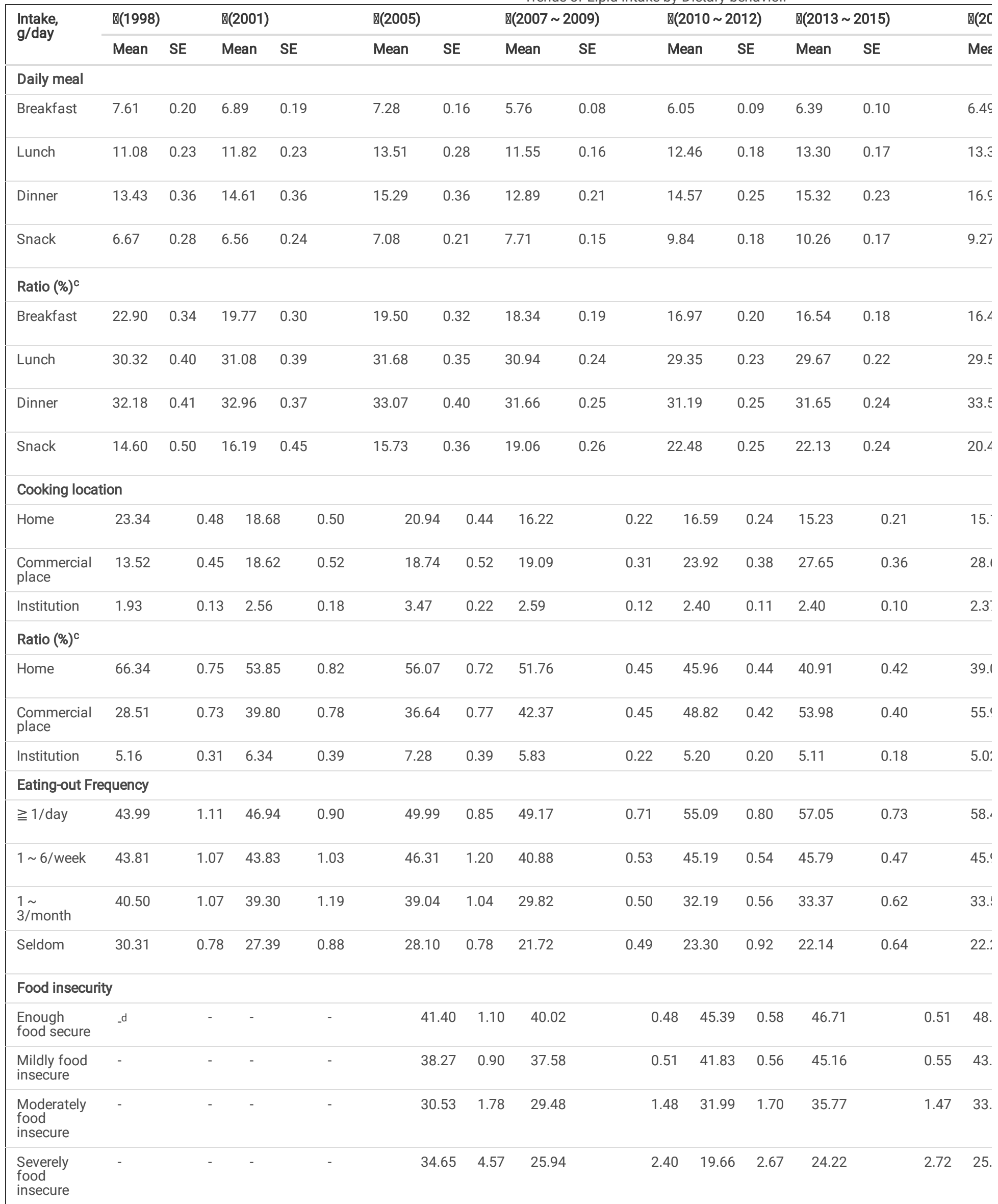

a All p for trend were calculated by surveyreg procedure of SAS. ${ }^{b}$ Adjusted for sex, age and energy intake. ${ }^{c}$ Ratio $(\%)=($ Lipid intake from each meal/Total lipic investigate questions related to this variable. 


\section{Lipid intake and ratio by food group classification}

The results of lipid intake and ratio by food groups are shown in Table 4. Overall, all plant and animal lipid intakes increased over the 20-year period (Unadjusted $p$ for trend $<0.001$, Adjusted $p$ for trend $<0.001$ ). In detail, lipid intake from grains, potatoes, sugars, nuts, seaweed, beverages, other plant foods and meats, eggs, dairy products, and other animal foods increased regardless of adjustment (Unadjusted $p$ for trend $<0.001$, Adjusted $p$ for trend $<0.001$ ). On the other hand, lipid intake from beans, vegetables, mushrooms, vegetable oils, fish and shellfish, and animal fats all decreased regardless of adjustment (Unadjusted $p$ for trend $<0.01$, Adjusted $p$ for trend $<0.001$ ). In the case of fruits, the intake declined significantly when adjusted by sex, age, and energy intake (Adjusted $p$ for trend $=0.0122$ ). The ratio of lipid intake from each food group contributed to the total lipid intake showed that the proportion of lipid intake from all plant foods decreased (Unadjusted $p$ for trend $<0.001$, Adjusted $p$ for trend $<0.001$ ), while that from animal fat foods increased significantly (Unadjusted $p$ for trend $<0.001$, Adjusted $p$ for trend $<0.001$ ). Specifically, the proportion of lipid intake from potatoes, sugars, seeds and nuts, seaweed, beverages, meats, eggs, dairy products, and other animal foods increased (Unadjusted $p$ for trend $<0.01$, Adjusted $p$ for trend $<0.001$ ). Meanwhile, the proportion of lipid intake from grains, beans, vegetables, mushrooms, fruits, vegetable oils, fish and shellfish, and animal fats decreased (Unadjusted $p$ for trend $<0.001$, Adjusted $p$ for trend $<0.001$ ). 
Table 4

Trends regarding Intake and ratio of Lipid from Food groups consumed per day.

\begin{tabular}{|c|c|c|c|c|c|c|c|c|c|c|c|c|c|c|c|}
\hline \multirow{2}{*}{$\begin{array}{l}\text { Intake, } \\
\text { g/day }\end{array}$} & \multicolumn{2}{|c|}{$\bigotimes(1998)$} & \multicolumn{2}{|c|}{$\rrbracket(2001)$} & \multicolumn{2}{|c|}{$\rrbracket(2005)$} & \multicolumn{2}{|c|}{$\rrbracket(2007 \sim 2009)$} & \multicolumn{2}{|c|}{$\llbracket(2010 \sim 2012)$} & \multicolumn{2}{|c|}{$\llbracket(2013 \sim 2015)$} & \multicolumn{2}{|c|}{$\llbracket(2016 \sim 2018)$} & \multirow{2}{*}{$\begin{array}{l}\text { Unadjus } \\
\text { p-trenda }\end{array}$} \\
\hline & Mean & SE & Mean & SE & Mean & SE & Mean & SE & Mean & SE & Mean & SE & Mean & SE & \\
\hline $\begin{array}{l}\text { Total plant } \\
\text { food }\end{array}$ & 19.68 & 0.32 & 20.90 & 0.35 & 23.58 & 0.34 & 21.78 & 0.21 & 24.29 & 0.24 & 25.27 & 0.24 & 24.02 & 0.23 & $<0.001(-$ \\
\hline $\begin{array}{l}\text { Cereals and } \\
\text { grain } \\
\text { products }\end{array}$ & 8.30 & 0.20 & 6.31 & 0.20 & 7.34 & 0.21 & 6.14 & 0.10 & 7.68 & 0.13 & 8.26 & 0.15 & 7.90 & 0.13 & $<0.001$ (- \\
\hline $\begin{array}{l}\text { Potatoes } \\
\text { and } \\
\text { starches }\end{array}$ & 0.28 & 0.07 & 0.10 & 0.02 & 0.10 & 0.02 & 0.12 & 0.01 & 0.18 & 0.02 & 0.33 & 0.03 & 0.29 & 0.02 & $<0.001(-$ \\
\hline $\begin{array}{l}\text { Sugars and } \\
\text { sweets }\end{array}$ & 0.05 & 0.02 & 0.05 & 0.01 & 0.08 & 0.02 & 0.10 & 0.01 & 0.20 & 0.02 & 0.36 & 0.03 & 0.32 & 0.02 & $<0.001(-$ \\
\hline $\begin{array}{l}\text { Legumes } \\
\text { and their } \\
\text { products }\end{array}$ & 1.60 & 0.05 & 2.13 & 0.06 & 2.63 & 0.07 & 2.56 & 0.05 & 2.36 & 0.05 & 2.29 & 0.04 & 1.89 & 0.04 & $0.0214(-$ \\
\hline $\begin{array}{l}\text { Seeds and } \\
\text { nuts }\end{array}$ & 0.62 & 0.05 & 0.63 & 0.05 & 1.46 & 0.07 & 0.96 & 0.04 & 1.31 & 0.05 & 1.76 & 0.06 & 1.70 & 0.05 & $<0.001(-$ \\
\hline Vegetables & 1.20 & 0.02 & 1.29 & 0.02 & 1.36 & 0.02 & 1.16 & 0.01 & 1.11 & 0.01 & 0.82 & 0.01 & 0.65 & 0.01 & $<0.001$ (- \\
\hline Mushrooms & 0.01 & 0.001 & 0.02 & 0.002 & 0.01 & 0.001 & 0.01 & 0.0004 & 0.01 & 0.0004 & 0.01 & 0.0003 & 0.01 & 0.0004 & $<0.001(-$ \\
\hline Fruits & 0.35 & 0.01 & 0.24 & 0.01 & 0.14 & 0.01 & 0.34 & 0.01 & 0.36 & 0.01 & 0.27 & 0.01 & 0.24 & 0.01 & $0.0647(-$ \\
\hline Seaweeds & 0.10 & 0.01 & 0.09 & 0.01 & 0.12 & 0.01 & 0.34 & 0.01 & 0.25 & 0.01 & 0.24 & 0.01 & 0.31 & 0.01 & $<0.001$ (- \\
\hline $\begin{array}{l}\text { Plant oils } \\
\text { and fats }\end{array}$ & 5.40 & 0.14 & 7.80 & 0.20 & 7.43 & 0.16 & 6.46 & 0.10 & 7.01 & 0.11 & 6.56 & 0.10 & 6.38 & 0.09 & 0.0097(- \\
\hline Beverages & 0.14 & 0.02 & 0.07 & 0.01 & 0.65 & 0.03 & 1.04 & 0.03 & 1.22 & 0.02 & 1.28 & 0.02 & 0.94 & 0.02 & $<0.001$ ( \\
\hline $\begin{array}{l}\text { Other plant } \\
\text { food }\end{array}$ & 1.62 & 0.06 & 2.17 & 0.08 & 2.26 & 0.07 & 2.56 & 0.07 & 2.61 & 0.07 & 3.10 & 0.09 & 3.37 & 0.09 & $<0.001$ (- \\
\hline $\begin{array}{l}\text { Total } \\
\text { animal } \\
\text { food }\end{array}$ & 19.12 & 0.44 & 18.97 & 0.44 & 19.58 & 0.39 & 16.13 & 0.26 & 18.63 & 0.28 & 20.01 & 0.25 & 22.12 & 0.26 & $<0.001(-$ \\
\hline $\begin{array}{l}\text { Meat, } \\
\text { poultry \& } \\
\text { products }\end{array}$ & 11.40 & 0.39 & 12.17 & 0.41 & 11.20 & 0.34 & 9.89 & 0.22 & 11.96 & 0.25 & 12.71 & 0.22 & 14.19 & 0.23 & $<0.001(-$ \\
\hline Eggs & 2.22 & 0.07 & 2.32 & 0.08 & 2.68 & 0.08 & 1.64 & 0.03 & 1.76 & 0.04 & 2.56 & 0.05 & 2.65 & 0.05 & $<0.001$ (- \\
\hline $\begin{array}{l}\text { Fish and } \\
\text { shellfish }\end{array}$ & 2.75 & 0.11 & 2.99 & 0.11 & 2.92 & 0.09 & 2.15 & 0.05 & 2.20 & 0.05 & 1.89 & 0.05 & 1.85 & 0.05 & $<0.001$ ( \\
\hline $\begin{array}{l}\text { Milks and } \\
\text { dairy } \\
\text { products }\end{array}$ & 1.75 & 0.09 & 1.41 & 0.06 & 2.03 & 0.08 & 2.28 & 0.06 & 2.57 & 0.07 & 2.64 & 0.06 & 3.12 & 0.08 & $<0.001$ ( \\
\hline $\begin{array}{l}\text { Animal oils } \\
\text { and fats }\end{array}$ & 0.99 & 0.05 & 0.06 & 0.01 & 0.73 & 0.03 & 0.13 & 0.01 & 0.13 & 0.01 & 0.20 & 0.01 & 0.23 & 0.01 & $<0.001(-$ \\
\hline $\begin{array}{l}\text { Other } \\
\text { animal } \\
\text { food }\end{array}$ & 0.01 & 0.004 & 0.02 & 0.02 & 0.01 & 0.005 & 0.03 & 0.01 & 0.01 & 0.002 & 0.01 & 0.002 & 0.08 & 0.01 & $<0.001(-$ \\
\hline \multicolumn{16}{|l|}{ Ratio $(\%)^{3)}$} \\
\hline $\begin{array}{l}\text { Total plant } \\
\text { food }\end{array}$ & 57.79 & 0.46 & 59.30 & 0.45 & 59.84 & 0.42 & 63.22 & 0.27 & 62.38 & 0.26 & 59.91 & 0.24 & 56.77 & 0.25 & $<0.001(-$ \\
\hline $\begin{array}{l}\text { Cereals and } \\
\text { grain } \\
\text { products }\end{array}$ & 24.51 & 0.37 & 16.95 & 0.34 & 16.88 & 0.32 & 17.14 & 0.19 & 19.17 & 0.21 & 18.84 & 0.21 & 18.01 & 0.20 & $<0.001$ (- \\
\hline $\begin{array}{l}\text { Potatoes } \\
\text { and } \\
\text { starches }\end{array}$ & 0.53 & 0.06 & 0.22 & 0.04 & 0.16 & 0.03 & 0.29 & 0.02 & 0.37 & 0.03 & 0.55 & 0.04 & 0.51 & 0.03 & $<0.001$ (- \\
\hline
\end{tabular}

${ }^{a}$ All p for trend were calculated by surveyreg procedure of SAS. ${ }^{b}$ Adjusted for sex, age and energy intake. ${ }^{c}$ Ratio $(\%)=($ Lipid intake from each food/Total lipic 


\begin{tabular}{|c|c|c|c|c|c|c|c|c|c|c|c|c|c|c|c|}
\hline \multirow{2}{*}{$\begin{array}{l}\text { Intake, } \\
\text { g/day }\end{array}$} & \multicolumn{2}{|c|}{$\llbracket(1998)$} & \multicolumn{2}{|c|}{$\llbracket(2001)$} & \multicolumn{2}{|c|}{$\mathbb{~}(2005)$} & \multicolumn{2}{|c|}{$\rrbracket(2007 \sim 2009)$} & \multicolumn{2}{|c|}{$\mathbb{\bigotimes}(2010 \sim 2012)$} & \multicolumn{2}{|c|}{$\rrbracket(2013 \sim 2015)$} & \multicolumn{2}{|c|}{$\llbracket(2016 \sim 2018)$} & \multirow{2}{*}{$\begin{array}{l}\text { Unadjus } \\
\text { p-trend }^{\mathrm{a}}\end{array}$} \\
\hline & Mean & SE & Mean & SE & Mean & SE & Mean & SE & Mean & SE & Mean & SE & Mean & SE & \\
\hline $\begin{array}{l}\text { Sugars and } \\
\text { sweets }\end{array}$ & 0.07 & 0.02 & 0.11 & 0.03 & 0.16 & 0.03 & 0.21 & 0.03 & 0.36 & 0.03 & 0.69 & 0.05 & 0.66 & 0.04 & $<0.001$ (- \\
\hline $\begin{array}{l}\text { Legumes } \\
\text { and their } \\
\text { products }\end{array}$ & 5.66 & 0.17 & 6.84 & 0.19 & 7.85 & 0.21 & 8.64 & 0.14 & 7.10 & 0.14 & 6.82 & 0.12 & 5.59 & 0.11 & $<0.001(-$ \\
\hline $\begin{array}{l}\text { Seeds and } \\
\text { nuts }\end{array}$ & 1.56 & 0.10 & 1.58 & 0.10 & 3.39 & 0.12 & 2.47 & 0.07 & 2.99 & 0.08 & 3.96 & 0.10 & 4.05 & 0.10 & $<0.001$ (- \\
\hline Vegetables & 4.84 & 0.10 & 5.43 & 0.14 & 4.83 & 0.10 & 4.71 & 0.06 & 4.04 & 0.06 & 2.86 & 0.04 & 2.19 & 0.03 & $<0.001$ (- \\
\hline Mushrooms & 0.04 & 0.003 & 0.08 & 0.01 & 0.04 & 0.004 & 0.03 & 0.001 & 0.03 & 0.001 & 0.02 & 0.001 & 0.03 & 0.001 & $<0.001$ - \\
\hline Fruits & 1.28 & 0.05 & 1.02 & 0.04 & 0.44 & 0.02 & 1.29 & 0.04 & 1.21 & 0.04 & 0.91 & 0.02 & 0.76 & 0.03 & $<0.001$ (- \\
\hline Seaweeds & 0.39 & 0.03 & 0.31 & 0.02 & 0.44 & 0.02 & 1.32 & 0.05 & 0.88 & 0.03 & 0.83 & 0.03 & 1.05 & 0.04 & $<0.001$ (- \\
\hline $\begin{array}{l}\text { Plant oils } \\
\text { and fats }\end{array}$ & 13.67 & 0.23 & 20.11 & 0.32 & 17.42 & 0.27 & 16.85 & 0.17 & 16.35 & 0.17 & 14.53 & 0.17 & 14.35 & 0.15 & $<0.001$ (- \\
\hline Beverages & 0.44 & 0.05 & 0.17 & 0.03 & 2.05 & 0.08 & 3.71 & 0.09 & 4.14 & 0.09 & 4.13 & 0.09 & 3.15 & 0.08 & $<0.001$ (- \\
\hline $\begin{array}{l}\text { Other plant } \\
\text { food }\end{array}$ & 4.80 & 0.13 & 6.48 & 0.19 & 6.19 & 0.14 & 6.56 & 0.11 & 5.74 & 0.10 & 5.77 & 0.11 & 6.42 & 0.12 & $0.0012(+$ \\
\hline $\begin{array}{l}\text { Total } \\
\text { animal } \\
\text { food }\end{array}$ & 42.21 & 0.46 & 40.70 & 0.45 & 40.16 & 0.42 & 36.78 & 0.27 & 37.62 & 0.26 & 40.09 & 0.24 & 43.23 & 0.25 & $<0.001$ - \\
\hline $\begin{array}{l}\text { Meat, } \\
\text { poultry \& } \\
\text { products }\end{array}$ & 21.39 & 0.49 & 22.08 & 0.45 & 19.36 & 0.40 & 19.61 & 0.26 & 20.89 & 0.27 & 22.64 & 0.25 & 24.52 & 0.27 & $<0.001$ (- \\
\hline Eggs & 5.49 & 0.17 & 5.91 & 0.19 & 5.91 & 0.15 & 4.43 & 0.08 & 4.37 & 0.08 & 6.09 & 0.11 & 6.41 & 0.11 & $<0.001$ (- \\
\hline $\begin{array}{l}\text { Fish and } \\
\text { shellfish }\end{array}$ & 7.97 & 0.26 & 8.85 & 0.28 & 7.89 & 0.20 & 6.67 & 0.12 & 5.92 & 0.11 & 4.95 & 0.10 & 4.93 & 0.10 & $<0.001$ (- \\
\hline $\begin{array}{l}\text { Milks and } \\
\text { dairy } \\
\text { products }\end{array}$ & 4.45 & 0.20 & 3.71 & 0.16 & 4.86 & 0.17 & 5.73 & 0.14 & 6.17 & 0.14 & 6.06 & 0.13 & 6.83 & 0.13 & $<0.001$ (- \\
\hline $\begin{array}{l}\text { Animal oils } \\
\text { and fats }\end{array}$ & 2.90 & 0.11 & 0.12 & 0.02 & 2.12 & 0.09 & 0.25 & 0.02 & 0.24 & 0.02 & 0.33 & 0.02 & 0.37 & 0.02 & $<0.001(-$ \\
\hline $\begin{array}{l}\text { Other } \\
\text { animal } \\
\text { food }\end{array}$ & 0.01 & 0.01 & 0.03 & 0.01 & 0.03 & 0.01 & 0.08 & 0.02 & 0.03 & 0.01 & 0.02 & 0.00 & 0.17 & 0.02 & $<0.001$ \\
\hline
\end{tabular}

${ }^{a}$ All p for trend were calculated by surveyreg procedure of SAS. ${ }^{b}$ Adjusted for sex, age and energy intake. ${ }^{c}$ Ratio $(\%)=($ Lipid intake from each food/Total lipic

Trends of proper lipid ratio contributed to energy according to the Dietary Reference Intakes for Koreans (KDRIs).

The results for the trends of lipid intake ratio contributed to energy, according to the $2015 \mathrm{KDRIs}$, are shown in Table 5. In the group with less than proper lipid ratio contributed to energy by $\mathrm{KDRI}(<15 \%)$, the ratio decreased by about $16.5 \%$ p (percentage points) for all individuals over the 20 -year period, falling from $48.5 \%$ in the first term to $32.0 \%$ in the seventh. The ratio fell by about $14.7 \%$ p (percentage points) in men and about $18.2 \%$ p (percentage points) in women. In terms of the prevalence of obesity in the group with less than proper lipid ratio contributed to energy, the prevalence rose by about $8.4 \% \mathrm{p}$ (percentage points) in all individuals, from $28.3 \%$ in the first term to $36.7 \%$ in the seventh. In men, it increased by about $13.1 \%$ p (percentage points), rising from $25.2 \%$ in the first term to $38.3 \%$ in the seventh term. In women, it rose by about $4.5 \%$ p (percentage points) over the 20 -year period, from $30.8 \%$ at the first term to $35.3 \%$ in the seventh. The prevalence of abdominal obesity increased by about $8.2 \%$ p (percentage points) in all individuals, from $24.2 \%$ in the first term to $32.4 \%$ in the seventh term. In men, the prevalence rose by $11.2 \%$ p (percentage points), increasing from $20.2 \%$ in the first term to $31.4 \%$ in the seventh. In women, meanwhile, it increased by $3.9 \%$ p (percentage points), rising from $27.4 \%$ in the first term to $33.3 \%$ in the seventh term. 
Table 5

Trends regarding Proper lipid ratio contributed to energy according to Korean Dietary Reference Intakes (KDRIs).

\begin{tabular}{|c|c|c|c|c|c|c|c|c|c|c|c|c|c|}
\hline $\mathbb{Q ( 1 9 9 8 )}$ & & $\otimes(2001)$ & & $\triangle(2005)$ & & $\begin{array}{l}\mathbb{Q}(2007 . \\
2009)\end{array}$ & & $\begin{array}{l}\bigotimes(2010 \\
2012)\end{array}$ & & $\begin{array}{l}\otimes(2013 \\
2015)\end{array}$ & & $\begin{array}{l}\bigotimes(2016 \sim \\
2018)\end{array}$ & \\
\hline $\begin{array}{l}n \text { or } \\
\text { mean }\end{array}$ & $\begin{array}{l}\%^{a} \\
\text { or } \\
\text { SE }\end{array}$ & $\begin{array}{l}n \text { or } \\
\text { mean }\end{array}$ & $\begin{array}{l}\% \text { or } \\
\text { SE }\end{array}$ & $\begin{array}{l}n \text { or } \\
\text { mean }\end{array}$ & $\begin{array}{l}\% \text { or } \\
\text { SE }\end{array}$ & $\begin{array}{l}n \text { or } \\
\text { mean }\end{array}$ & $\begin{array}{l}\% \text { or } \\
\text { SE }\end{array}$ & $\begin{array}{l}n \text { or } \\
\text { mean }\end{array}$ & $\begin{array}{l}\% \text { or } \\
\text { SE }\end{array}$ & $\begin{array}{l}n \text { or } \\
\text { mean }\end{array}$ & $\begin{array}{l}\% \text { or } \\
\text { SE }\end{array}$ & $\begin{array}{l}n \text { or } \\
\text { mean }\end{array}$ & $\begin{array}{l}\% \text { or } \\
\text { SE }\end{array}$ \\
\hline
\end{tabular}

Less than proper lipid ratio contributed to energy $(<15 \%)$

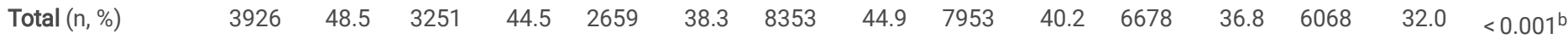

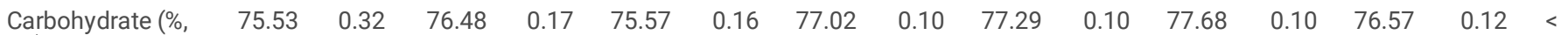

SE)

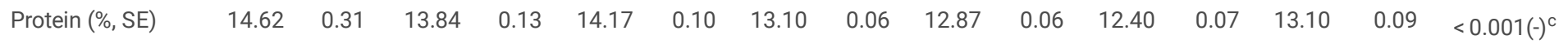

$\begin{array}{llllllllllllllll}\text { Lipid }(\%, \text { SE) } & 9.84 & 0.09 & 9.68 & 0.09 & 10.26 & 0.09 & 9.88 & 0.05 & 9.84 & 0.06 & 9.92 & 0.05 & 10.33 & 0.06 & <\end{array}$

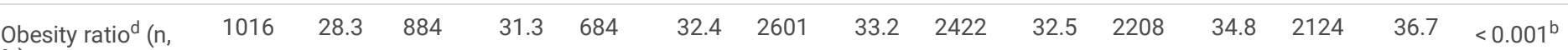

$\%)$

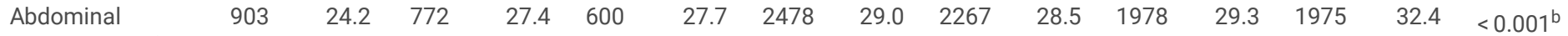

obesity ratio ${ }^{\mathrm{e}}(\mathrm{n}$,

$\%)$

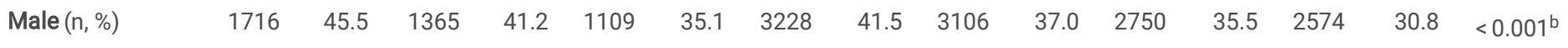

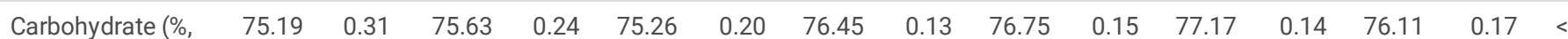

SE)

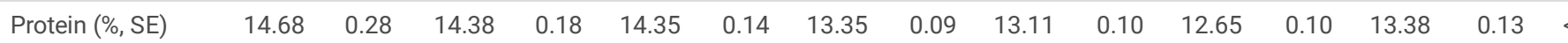

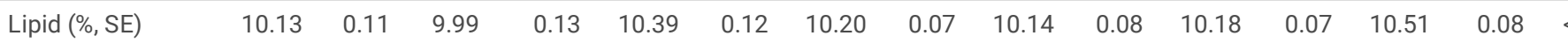

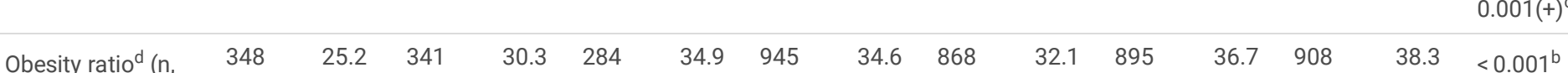

$\%)$

$\begin{array}{lllllllllllllll}\text { Abdominal } & 298 & 20.2 & 271 & 23.2 & 222 & 26.6 & 855 & 27.7 & 762 & 26.2 & 751 & 28.8 & 797 & 31.4\end{array}$

obesity ratio $^{\mathrm{e}}(\mathrm{n}$,

$\%)$

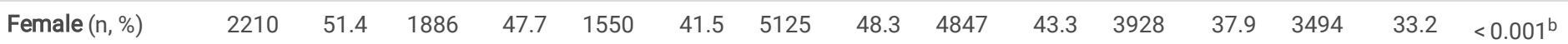

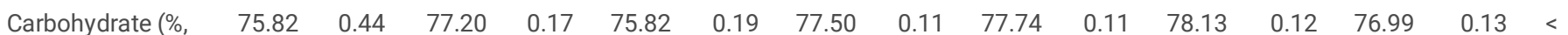

SE)

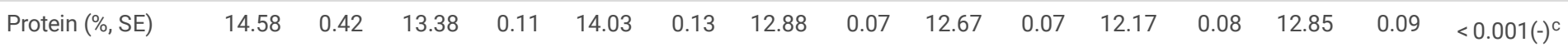

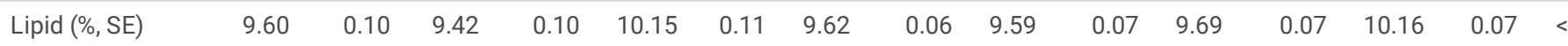

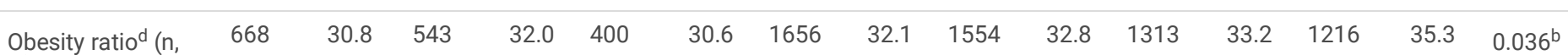

$\%)$

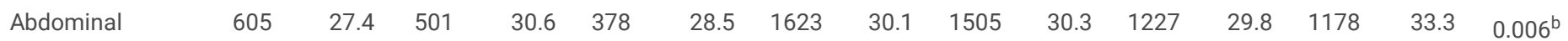

obesity ratio ${ }^{\mathrm{e}}(\mathrm{n}$,

$\%)$

Proper lipid ratio contributed to energy (15 30\%)

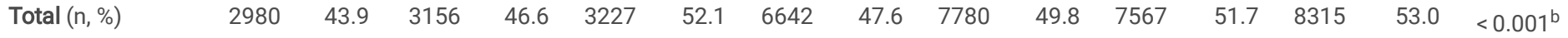

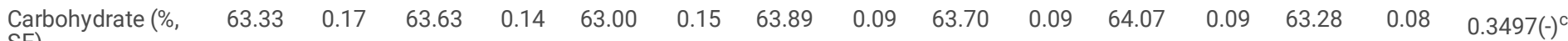

SE)

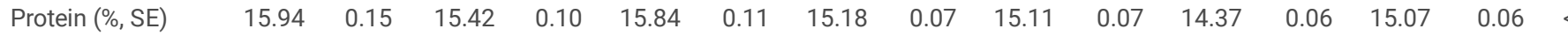

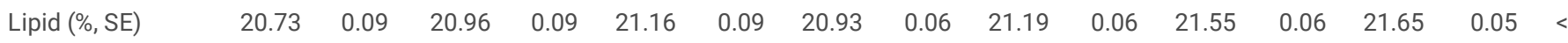

$0.001(+)^{\mathrm{c}}$

$0.001(+)^{\mathrm{c}}$

${ }^{a}$ Weighted $\%,{ }^{b} p$-value by chi-square, ${ }^{c} p$ for trend was calculated by surveyreg procedure of SAS. ${ }^{d}$ Obesity: BMI $\geqq 25 \mathrm{~kg} / \mathrm{m}^{2}$, e Abdominal obesity: Meal (Waist circumference $\geq 90 \mathrm{~cm}$ ), Female (Waist circumference $\geq 85 \mathrm{~cm}$ ). 


\begin{tabular}{|c|c|c|c|c|c|c|c|c|c|c|c|c|c|c|c|}
\hline & \multicolumn{2}{|c|}{ 区(1998) } & \multicolumn{2}{|c|}{$\rrbracket(2001)$} & \multicolumn{2}{|c|}{ 凹(2005) } & \multicolumn{2}{|c|}{$\begin{array}{l}\bigotimes(2007 \sim \\
2009)\end{array}$} & \multicolumn{2}{|c|}{$\begin{array}{l}\bigotimes(2010 \sim \\
2012)\end{array}$} & \multicolumn{2}{|c|}{$\begin{array}{l}\bigotimes(2013 \sim \\
2015)\end{array}$} & \multicolumn{2}{|c|}{$\begin{array}{l}\bigotimes(2016 \sim ~ \\
2018)\end{array}$} & \multirow[t]{2}{*}{ p-value } \\
\hline & $\begin{array}{l}n \text { or } \\
\text { mean }\end{array}$ & $\begin{array}{l}\% a \\
\text { or } \\
\text { SE }\end{array}$ & $\begin{array}{l}n \text { or } \\
\text { mean }\end{array}$ & $\begin{array}{l}\% \text { or } \\
\text { SE }\end{array}$ & $\begin{array}{l}n \text { or } \\
\text { mean }\end{array}$ & $\begin{array}{l}\text { \% or } \\
\text { SE }\end{array}$ & $\begin{array}{l}n \text { or } \\
\text { mean }\end{array}$ & $\begin{array}{l}\% \text { or } \\
\text { SE }\end{array}$ & $\begin{array}{l}n \text { or } \\
\text { mean }\end{array}$ & $\begin{array}{l}\% \text { or } \\
\text { SE }\end{array}$ & $\begin{array}{l}n \text { or } \\
\text { mean }\end{array}$ & $\begin{array}{l}\% \text { or } \\
\text { SE }\end{array}$ & $\begin{array}{l}n \text { or } \\
\text { mean }\end{array}$ & $\begin{array}{l}\% \text { or } \\
\text { SE }\end{array}$ & \\
\hline $\begin{array}{l}\text { Obesity ratio }{ }^{d}(n, \\
\%)\end{array}$ & 647 & 23.5 & 704 & 27.8 & 707 & 30.4 & 1851 & 30.3 & 2244 & 31.8 & 2266 & 32.1 & 2610 & 33.9 & $<0.001^{b}$ \\
\hline $\begin{array}{l}\text { Abdominal } \\
\text { obesity ratio }(n, \\
\%)\end{array}$ & 509 & 17.3 & 530 & 20.4 & 506 & 21.4 & 1509 & 22.2 & 1695 & 21.9 & 1696 & 22.7 & 2177 & 26.9 & $<0.001^{\mathrm{b}}$ \\
\hline Male (n, \%) & 1481 & 46.4 & 1564 & 49.6 & 1510 & 54.7 & 2884 & 50.8 & 3337 & 52.8 & 3232 & 53.5 & 3624 & 54.9 & $<0.001^{b}$ \\
\hline $\begin{array}{l}\text { Carbohydrate (\%, } \\
\text { SE) }\end{array}$ & 63.20 & 0.23 & 63.51 & 0.15 & 63.10 & 0.18 & 63.80 & 0.14 & 63.81 & 0.13 & 64.07 & 0.12 & 63.29 & 0.12 & $0.2490(+)^{c}$ \\
\hline Protein $(\%, S E)$ & 16.20 & 0.19 & 15.61 & 0.11 & 15.71 & 0.13 & 15.22 & 0.10 & 15.05 & 0.09 & 14.38 & 0.08 & 15.15 & 0.09 & $<0.001(-)^{\mathrm{c}}$ \\
\hline Lipid (\%, SE) & 20.61 & 0.11 & 20.88 & 0.11 & 21.19 & 0.11 & 20.98 & 0.08 & 21.15 & 0.09 & 21.55 & 0.08 & 21.57 & 0.07 & $0.0049(+)^{\mathrm{c}}$ \\
\hline $\begin{array}{l}\text { Obesity ratio }{ }^{d}(n, \\
\%)\end{array}$ & 329 & 24.8 & 370 & 29.9 & 342 & 33.6 & 976 & 37.4 & 1133 & 38.2 & 1160 & 39.4 & 1401 & 42.4 & $<0.001^{b}$ \\
\hline $\begin{array}{l}\text { Abdominal } \\
\text { obesity ratio }{ }^{\mathrm{e}}(\mathrm{n} \text {, } \\
\%)\end{array}$ & 249 & 17.9 & 263 & 20.2 & 249 & 23.7 & 684 & 23.9 & 797 & 23.9 & 832 & 26.6 & 1130 & 32.8 & $<0.001^{b}$ \\
\hline Female (n, \%) & 1499 & 41.4 & 1592 & 43.7 & 1717 & 49.5 & 3758 & 44.5 & 4443 & 46.9 & 4335 & 49.9 & 4691 & 51.1 & $<0.001^{b}$ \\
\hline $\begin{array}{l}\text { Carbohydrate (\%, } \\
\text { SE) }\end{array}$ & 63.47 & 0.21 & 63.75 & 0.20 & 62.89 & 0.21 & 63.98 & 0.11 & 63.58 & 0.12 & 64.08 & 0.11 & 63.27 & 0.11 & $0.8057(+)^{\mathrm{c}}$ \\
\hline Protein $(\%, S E)$ & 15.66 & 0.17 & 15.21 & 0.13 & 15.98 & 0.17 & 15.13 & 0.08 & 15.18 & 0.08 & 14.37 & 0.07 & 14.99 & 0.07 & $<0.001(-)^{\mathrm{c}}$ \\
\hline Lipid (\%, SE) & 20.87 & 0.12 & 21.04 & 0.13 & 21.13 & 0.11 & 20.88 & 0.08 & 21.25 & 0.07 & 21.56 & 0.07 & 21.73 & 0.07 & $\begin{array}{l}< \\
0.001(+)^{\mathrm{C}}\end{array}$ \\
\hline $\begin{array}{l}\text { Obesity ratio }{ }^{d}(n, \\
\%)\end{array}$ & 318 & 22.1 & 334 & 25.6 & 365 & 27.4 & 875 & 22.7 & 1111 & 25.2 & 1106 & 24.8 & 1209 & 25.3 & $<0.001^{b}$ \\
\hline $\begin{array}{l}\text { Abdominal } \\
\text { obesity ratio }{ }^{\mathrm{e}}(\mathrm{n} \text {, } \\
\text { \%) }\end{array}$ & 260 & 16.8 & 267 & 20.6 & 257 & 19.4 & 825 & 20.4 & 898 & 19.8 & 864 & 18.7 & 1047 & 20.9 & $0.094^{b}$ \\
\hline \multicolumn{16}{|c|}{ More than Proper lipid ratio contributed to energy $(>30 \%)$} \\
\hline Total (n, \%) & 498 & 7.6 & 580 & 8.9 & 547 & 9.6 & 944 & 7.5 & 1397 & 10.0 & 1527 & 11.6 & 2174 & 15.0 & $<0.001^{\mathrm{b}}$ \\
\hline $\begin{array}{l}\text { Carbohydrate (\%, } \\
\text { SE) }\end{array}$ & 45.72 & 0.55 & 46.64 & 0.43 & 47.33 & 0.41 & 48.11 & 0.29 & 47.92 & 0.25 & 49.37 & 0.18 & 47.86 & 0.19 & $\begin{array}{l}< \\
0.001(+)^{\mathrm{c}}\end{array}$ \\
\hline Protein $(\%, S E)$ & 17.01 & 0.29 & 16.55 & 0.22 & 16.31 & 0.22 & 16.17 & 0.16 & 16.45 & 0.14 & 15.13 & 0.11 & 15.80 & 0.11 & $<0.001(-)^{\mathrm{c}}$ \\
\hline Lipid (\%, SE) & 37.27 & 0.43 & 36.81 & 0.35 & 36.36 & 0.30 & 35.72 & 0.23 & 35.64 & 0.19 & 35.50 & 0.14 & 36.34 & 0.14 & $0.0545(-)^{\mathrm{c}}$ \\
\hline $\begin{array}{l}\text { Obesity ratio }{ }^{d}(n, \\
\%)\end{array}$ & 91 & 20.4 & 128 & 28.5 & 127 & 32.9 & 226 & 27.7 & 374 & 30.7 & 408 & 29.5 & 683 & 34.5 & $0.002^{b}$ \\
\hline $\begin{array}{l}\text { Abdominal } \\
\text { obesity ratio }(\mathrm{n} \text {, } \\
\%)\end{array}$ & 69 & 15.5 & 96 & 19.0 & 90 & 22.2 & 170 & 19.0 & 257 & 20.7 & 291 & 20.3 & 544 & 26.1 & $<0.001^{b}$ \\
\hline Male (n, \%) & 237 & 8.1 & 275 & 9.2 & 248 & 10.1 & 376 & 7.7 & 544 & 10.2 & 572 & 11.0 & 832 & 14.3 & $<0.001^{b}$ \\
\hline $\begin{array}{l}\text { Carbohydrate (\%, } \\
\text { SE) }\end{array}$ & 45.49 & 0.78 & 46.06 & 0.63 & 47.94 & 0.51 & 48.44 & 0.40 & 48.16 & 0.37 & 49.72 & 0.28 & 47.64 & 0.30 & $0.0014(+)^{\mathrm{c}}$ \\
\hline Protein $(\%, S E)$ & 17.30 & 0.33 & 16.77 & 0.28 & 16.22 & 0.30 & 16.32 & 0.23 & 16.59 & 0.23 & 15.08 & 0.18 & 15.89 & 0.17 & $<0.001(-)^{\mathrm{c}}$ \\
\hline Lipid (\%, SE) & 37.21 & 0.65 & 37.17 & 0.50 & 35.83 & 0.40 & 35.24 & 0.32 & 35.24 & 0.26 & 35.21 & 0.24 & 36.47 & 0.23 & $0.4108(-)^{c}$ \\
\hline $\begin{array}{l}\text { Obesity ratio }{ }^{d}(n, \\
\%)\end{array}$ & 50 & 25.7 & 78 & 39.4 & 73 & 43.5 & 115 & 36.6 & 192 & 39.1 & 209 & 40.4 & 359 & 46.8 & $0.007^{b}$ \\
\hline
\end{tabular}




\begin{tabular}{|c|c|c|c|c|c|c|c|c|c|c|c|c|c|c|c|}
\hline & \multicolumn{2}{|c|}{$凶(1998)$} & \multicolumn{2}{|c|}{$\rrbracket(2001)$} & \multicolumn{2}{|c|}{$\llbracket(2005)$} & \multicolumn{2}{|c|}{$\begin{array}{l}\bigotimes(2007 \sim \\
2009)\end{array}$} & \multicolumn{2}{|c|}{$\begin{array}{l}\mathbb{X ( 2 0 1 0 ~ \sim ~} \\
2012)\end{array}$} & \multicolumn{2}{|c|}{$\begin{array}{l}\bigotimes(2013 \sim \\
2015)\end{array}$} & \multicolumn{2}{|c|}{$\begin{array}{l}\text { 囚(2016 } \\
2018)\end{array}$} & \multirow[t]{2}{*}{ p-value } \\
\hline & $\begin{array}{l}n \text { or } \\
\text { mean }\end{array}$ & $\begin{array}{l}\%^{a} \\
\text { or } \\
\text { SE }\end{array}$ & $\begin{array}{l}n \text { or } \\
\text { mean }\end{array}$ & $\begin{array}{l}\% \text { or } \\
\text { SE }\end{array}$ & $\begin{array}{l}n \text { or } \\
\text { mean }\end{array}$ & $\begin{array}{l}\text { \% or } \\
\text { SE }\end{array}$ & $\begin{array}{l}n \text { or } \\
\text { mean }\end{array}$ & $\begin{array}{l}\text { \% or } \\
\text { SE }\end{array}$ & $\begin{array}{l}n \text { or } \\
\text { mean }\end{array}$ & $\begin{array}{l}\% \text { or } \\
\mathrm{SE}\end{array}$ & $\begin{array}{l}n \text { or } \\
\text { mean }\end{array}$ & $\begin{array}{l}\% \text { or } \\
\text { SE }\end{array}$ & $\begin{array}{l}n \text { or } \\
\text { mean }\end{array}$ & $\begin{array}{l}\% \text { or } \\
\text { SE }\end{array}$ & \\
\hline $\begin{array}{l}\text { Abdominal } \\
\text { obesity ratio }{ }^{\mathrm{e}}(\mathrm{n} \text {, } \\
\%)\end{array}$ & 36 & 18.5 & 59 & 26.6 & 49 & 27.6 & 78 & 24.1 & 129 & 26.3 & 140 & 26.2 & 283 & 35.0 & $0.001^{b}$ \\
\hline Female (n, \%) & 261 & 7.2 & 305 & 8.6 & 299 & 9.1 & 568 & 7.3 & 853 & 9.8 & 955 & 12.1 & 1342 & 15.7 & $<0.001^{b}$ \\
\hline $\begin{array}{l}\text { Carbohydrate (\%, } \\
\text { SE) }\end{array}$ & 45.98 & 0.70 & 47.24 & 0.52 & 46.67 & 0.51 & 47.76 & 0.42 & 47.67 & 0.32 & 49.07 & 0.24 & 48.07 & 0.23 & $\begin{array}{l}< \\
0.001(+)^{\mathrm{C}}\end{array}$ \\
\hline Protein $(\%, S E)$ & 16.69 & 0.39 & 16.32 & 0.34 & 16.41 & 0.28 & 16.02 & 0.22 & 16.30 & 0.18 & 15.17 & 0.15 & 15.72 & 0.15 & $<0.001(-)^{\mathrm{c}}$ \\
\hline Lipid (\%, SE) & 37.33 & 0.52 & 36.44 & 0.40 & 36.92 & 0.35 & 36.22 & 0.32 & 36.03 & 0.26 & 35.76 & 0.17 & 36.22 & 0.17 & $0.0210(-)^{\mathrm{c}}$ \\
\hline $\begin{array}{l}\text { Obesity ratio }{ }^{\mathrm{d}}(\mathrm{n}, \\
\%)\end{array}$ & 41 & 15.4 & 50 & 18.6 & 54 & 23.3 & 111 & 19.3 & 182 & 22.5 & 199 & 20.4 & 324 & 23.9 & $0.124^{b}$ \\
\hline $\begin{array}{l}\text { Abdominal } \\
\text { obesity ratio } \text { (n, }^{\text {e }} \\
\text { \%) }\end{array}$ & 33 & 12.8 & 37 & 12.1 & 41 & 17.3 & 92 & 14.3 & 128 & 15.3 & 151 & 15.4 & 261 & 18.6 & $0.106^{b}$ \\
\hline
\end{tabular}

The proper lipid ratio contributed to energy by KDRIs ranges from 15-30\%. In all individuals, the ratio increased by $10.0 \%$ p (percentage points) over the 20 year period, rising from $43.9 \%$ in the first term to $53.0 \%$ in the seventh. The ratio increased by about $8.5 \%$ p (percentage points) in men and $10 \% p$ (percentage points) in women over the 20 -year period. In terms of the prevalence of obesity in the group with proper lipid ratio contributed to energy, it increased by $10.4 \% \mathrm{p}$ (percentage points) in all individuals, from $23.5 \%$ in the first term to $33.9 \%$ in the seventh. In men, it increased by $17.6 \%$ p (percentage points), from $24.8 \%$ in the first term to $42.4 \%$ in the seventh. In women, the prevalence rose by $3.2 \%$ p (percentage points), from $22.1 \%$ in the first term to $25.3 \%$ in the seventh. For the prevalence of abdominal obesity, the prevalence rose by $9.6 \% \mathrm{p}$ (percentage points) in all individuals, from $17.3 \%$ in the first term to $26.9 \%$ in the seventh. In men, it rose by $14.9 \%$ p (percentage points), from $17.9 \%$ in the first term to $32.8 \%$ in the seventh. In women, it increased by about $4.1 \%$ p (percentage points), rising from $16.8 \%$ in the first term to $20.9 \%$ in the seventh. In the group with more than $30.0 \%$ of proper lipid ratio contributed to energy, the prevalence doubled from $7.6 \%$ in the first term to $15.0 \%$ in the seventh, with a $6.2 \%$ p (percentage points) increase in men and slightly more than doubling in women (from $7.2 \%$ in the first term to $15.7 \%$ in the seventh). The prevalence of obesity in this group increased by $14.1 \%$ (percentage points) in all individuals over the 20 -year period, with a $21.1 \% \mathrm{p}$ (percentage points) increase in men and $8.5 \% \mathrm{p}$ (percentage points) increase in women. The prevalence of abdominal obesity in all individuals increased by about $10.6 \% \mathrm{p}$ (percentage points), rising from $15.5 \%$ in the first term to $26.1 \%$ in the seventh. In men, it increased by $17.5 \% \mathrm{p}$ (percentage points), from $18.5 \%$ in the first term to $35.0 \%$ in the seventh. In women, meanwhile, it increased by $5.8 \%$ p (percentage points), from $12.8 \% \mathrm{p}$ (percentage points) in the first term to $18.6 \%$ in the seventh term.

\section{Discussion}

This study analyzed the lipid intake trends of Korean adults using the lipid intake data included in the KNHANES data spanning the 20-year period from 1998 to 2018. With this, factors related to the lipid intake of Korean adults over the 20-year period were investigated.

The study results showed that the lipid intake ratio contributed to energy ranged from $16-21 \%$ on average for all individuals, men, and women. This level was included in the proper range of the lipid ratio contributed to energy of 15-30\% recommended by the $2015 \mathrm{KDRIs}$ [27]. Lipid intake increased significantly from the first to the seventh term for all individuals $(+7.34 \mathrm{~g})$, men $(+9.71 \mathrm{~g})$, and women $(+4.93 \mathrm{~g})$. The lipid intake ratio contributed to energy also rose significantly over the same period for all individuals $(+3.52 \% \mathrm{p})$, men $(+3.12 \% \mathrm{p})$, and women $(+3.90 \% \mathrm{p})$. Song et al. [12] analyzed the lipid intake trends of Korean adults over an eight-year period (2007-2015) and reported that energy, total lipid, saturated fatty acids, unsaturated fatty acids, n-3 fatty acids, and n-6 fatty acids all increased steadily over the period. However, in a recent study that used the 2016-2017 KNHANES data [22], the intake ratio of polyunsaturated fatty acids remained unchanged, but that of saturated fatty acids increased. Overall, the lipid intake of Korean adults seems to be increasing. It is known that fats not only supply energy to the human body but are also used as a component of cell membranes and aid the absorption of fat-soluble vitamins [5]. These fats can also be transformed into other fatty acids according to the body's needs and serve a function in immune responses and as various chemical messengers [6]. On the other hand, lipids can provide more than twice the energy of carbohydrates or proteins, and thus excessive lipid intake can increase the risk of obesity. Particularly, excessive intake of saturated fatty acids or trans fatty acids can increase the risk of cerebrovascular and cardiovascular disorders, dyslipidemia, diabetes, and hypertension [9]. Therefore, it is considered that data are needed for dietary guidelines and nutrition education in the future to prevent increases in lipid intake.

Lipid intake by type of meal showed that intake via breakfast decreased continuously but increased through lunch, dinner, and snacks over the 20-year period. This is thought to be related to the significant increase in the proportion of people skipping breakfast, which increased from $11.8 \%$ in 1998 to $26.0 \%$ in $2016-$ 2018, more than doubling over the 20-year study period. People who skip breakfast tend to eat more food at lunch or dinner, particularly high-fat meats. 
Studies have shown that skipping breakfast is highly correlated to obesity prevalence, high serum cholesterol, and high blood pressure. In this study, the group that consumed less energy at breakfast showed a higher fat-to-energy ratio and protein-to-energy ratio and lower carbohydrate-to-energy ratio [28-31].

The lipid intake by cooking location showed that intake increased significantly through meals prepared by commercial food services. Previous studies [32-34] also reported similar results of increased lipid intake from the meals provided by commercial food services. In a study conducted on the eating-out trends of Korean adults for the 14 years from 1998 to 2012, the lipid intake ratio of eating out increased from 19.2\% in 1998 to $21.7 \%$ in 2012 [32]. Also, a study on nutrient intake changes caused by eating out from 2010 to 2015 showed that carbohydrate and protein intakes decreased, while lipid intake increased continuously. The intake of refined processed foods and high-fat foods increases the more one eats out and consumes convenience foods. Moreover, food delivery has expanded due to the increased number of women in the workplace, reduced family size, and increased number of one-person households, in line with the social and economic changes in Korea [35].

Lipid intake by level of food security showed that the "enough food secure," "mildly food insecure," and "moderately food insecure" groups all increased significantly except "severely food insecure". This trend may be related that most of meals and processed foods contain lipid.

According to the results of this study, total plant and animal lipid intake has increased over the 20-year period from 1998 to 2018 . Specifically, the ratio of lipid intake from potatoes, sugars, seeds and nuts, seaweed, beverages, meats, eggs, dairy products, and other animal foods has increased, while that from grains, beans, vegetables, mushrooms, fruits, vegetable oils, fish and shellfish, and animal fats has decreased. Supporting this result, the survey of lipid intake from major foods conducted using the 2013 KNHANES data showed that total fats and fatty acids from pork were the major food source for lipid intake [11]. Also, according to result of previous study [36], the foods that contributed most to the lipid intake of Koreans were pork, soybean oil, beef, eggs, and ramen, showing a high representation of animal foods. Because fats are present in various types and forms in foods, it is believed that the type of fatty acid, rather than the total lipid intake, has a greater effect on the blood lipid profile. In particular, monounsaturated fatty acids and n-3 fatty acids are largely contained in plant foods such as beans, seeds, and nuts, while polyunsaturated fatty acids such as eicosapentaenoic acid (EPA) and docosahexaenoic acid (DHA) are present in high concentration in fish. Thus, proper education on and intake of various types of fatty acids is recommended [11, 19].

Although it was not investigated in this study, the lipid intake might be different not only by type of meal but also diet. Recently, diets have emerged as an important factor, as diets such as the Mediterranean diet and USDA diet, which emphasize vegetables, fruits, whole grains, low-fat dairy products, fish, and fowl, are reported to reduce the risk of dyslipidemia and cardiovascular/cerebrovascular diseases [27, 37]. Also, it has been reported that diets affect obesity and thus are considered to be significantly related to genes associated with chronic disorders [27, 38, 39]. In the future, epidemiology and clinical intervention research should be performed on the basis of the results of this study on Koreans.

The proportion of individuals who had a proper fat ratio contributed to energy by the KDRIs (fat ratio range: $15-30 \%$ ) increased by about $10.0 \% \mathrm{p}$ (percentage points) over the 20 -year period, rising from $43.9 \%$ in the first term (1998) to $53.0 \%$ in the seventh (2016 2018). This suggests that lipid intake has increased in the diets of Koreans compared to protein and carbohydrate intakes. However, several studies recently reported that groups with high carbohydrate intake, rather than lipid intake, were at higher risk of chronic diseases, including obesity [40,41]. In this study, the group with high carbohydrate intake ratio contributed to energy was the group with less than proper fat ratio contributed to energy ( $<15 \%)$, and the carbohydrate intake ratio was $75-78 \%$. This exceeds the carbohydrate intake ratio by about $10-13 \%$ according to the $2015 \mathrm{KDRI}(55-65 \%)$. The prevalence of obesity and abdominal obesity in this group, such as the obesity prevalence (38.3\%) in men in the seventh term (2016 2018), was about 4.1-8.5\% lower than that of the groups with proper (lipid intake ratio: $15-$ $30 \%$, obesity prevalence: $42.4 \%$ ) or more than proper fat ratio contributed to energy (lipid intake ratio: over $30 \%$, obesity prevalence: $46.8 \%$ ) according to the 2015 KDRIs. This is slightly different from the results of previous studies on high carbohydrate intake. However, in the case of carbohydrates, a highcarbohydrate diet featuring foods with high dietary fiber content reportedly reduces blood lipid levels, including triglycerides, more than a carbohydrate diet with foods with low fiber content [42]. Although the details should be checked further, it is believed that the obesity prevalence in men in this study might be explained by the results reported by such previous studies. Therefore, the type of carbohydrates ingested and their effects should be considered in future studies. Also, the difference in the obesity prevalence between this study and other previous studies should be confirmed in detail in the future, although there might be a difference due to the types of fatty acids. To support this, in-depth studies on the relationship between the intake of fats and fatty acids and chronic diseases, including obesity, will be needed, along with meta-analyses and systemic reviews that investigate disease prevalence more systematically and scientifically using long-term follow-up cohort study data such as the Korean Genome and Epidemiology Study (KoGES), which has been conducted since 2001 and recently completed its seventh follow-up study, and accumulated data.

As the association between the KNHANES data of the Ministry of Health and Welfare and the cause of death statistics of Statistics Korea [43] becomes possible in Korea, studies similar to the previous study on Americans, in which the mortality rates of high-fat diet groups and high-carbohydrate diet groups were compared [44], will be able to be conducted on Koreans.

This study has some limitations. First, we could not assess the actual intake of total lipid from the participants' diet because of collecting the one-day $24-\mathrm{h}$ recall data. However, the results of this study may be generalized to Korean adults due to KNHANES data is based on a large nationally representative sample.

Second, analysis of trends using data on various fatty acids data was not performed, as reported in the previous study by Song \& Shim [10], and total lipid intake was analyzed according to general characteristics, dietary behavior, food groups, and KDRIs criteria. This is because fatty acid data have been collected since the 2016 KNHANES and the food code was the same as in the 2007-2015 KNHANES data, and fatty acid data seemed to be applied to the relevant years' KNHANES data and used in the study. To enable detailed studies on various lipid intake trends to be conducted in Korea in the future, the food and meal codes should be standardized for the KNHANES data prior to 2007, and fatty acid data should be listed for all terms of the KNHANES data. In the future, lipid intake analysis should be performed for foods listed in the food frequency questionnaire conducted from 2012 to 2016 , and thus studies on the annual lipid intake of Koreans, which cannot be deduced by the 24-hour recall survey, and comparative studies should be performed. 


\section{Conclusions}

This study was undertaken to analyze 20-year trend regarding the lipid intake of Korean adults according to general characteristics, dietary behavior, food groups, and the KDRIs, using KNHANES data. The lipid intake increased significantly in all individuals $(+7.34 \mathrm{~g})$, men $(+9.71 \mathrm{~g})$, and women $(+4.93 \mathrm{~g})(\mathrm{p}$ for trend $<0.001)$ from the first to the seventh term. The lipid ratio contributed to energy increased significantly in all individuals $(+3.52 \%$ percentage points), men $(+3.12 \%$ percentage points), and women $(+3.90 \%$ percentage points) over the 20 -year period ( $p$ for trend $<0.001)$. Lipid intake increased significantly overall as well as by sex, age, residential area, education level (except below 12 years of education), and presence of obesity and abdominal obesity increased over the 20-year period. Total plant and animal lipid intake has increased over the 20-year period from 1998 to 2018 . Specifically, the ratio of lipid intake from potatoes, sugars, seeds and nuts, seaweed, beverages, meats, eggs, dairy products, and other animal foods has increased, while that from grains, beans, vegetables, mushrooms, fruits, vegetable oils, fish and shellfish, and animal fats has decreased. The results of this study will aid in the preparation of basic data for nutrition policy and proper nutrition and dietary education with the aim of improving the diets of Koreans nationwide.

\section{Abbreviations}

BMI: Body mass index; Cl: Confidence interval; KDRIs: Dietary Reference Intakes for Koreans; KNHANES: Korea National Health and Nutrition Examination Survey; OR: Odds ratio; SE: Standard error; KoGES: Korean Genome and Epidemiology Study; USDA: United States Department of Agriculture; EPA: Eicosapentaenoic acid; DHA: Docosahexaenoic acid; KCDC: Korea Centers for Disease Control and Prevention; IRB: Institutional Review Board

\section{Declarations}

\section{Acknowledgements}

Not applicable.

\section{Author Contributions}

All authors had a significant role in this study. YS Kwon contributed to the writing and the data analysis of the manuscript. S Ju and Y Hwang contributed to study design of this study; S Ju and $\mathrm{H}$ Chu has primary responsibility for the final content. All authors read and approved the final manuscript.

\section{Funding}

This research was funded by the agro-food based basic research of the Korea Rural Development Administration grant (Project No. PJ01347101).

\section{Availability of data and materials}

The datasets used and analyzed during this present study are available in https://knhanes.cdc.go.kr/knhanes/eng/index.do.

\section{Ethics approval and consent to participate}

The KNHANES data used in this study were approved by the KCDC IRB (approval numbers: 2007-02CON-04-P, 2008-04EXP-01-C, 2009-01C0N-03-2C, 201002CON-21-C, 2011-02CON-06-C, 2012-01EXP-01-2C, 2013-07CON-03-4C, 2013-12EXP-03-5C, and 2018-01-03-P-A). Among these, the 2015-2017 KNHANES survey was conducted without the deliberation of the IRB, because studies were to be conducted directly by the government for public welfare, according to Article 2, Subparagraph 1, of the Bioethics and Safety Act and Article 2, Paragraph 2, Subparagraph 1, of the Enforcement Regulations of the same Act. However, the IRB deliberation has been reopened for the collection of human materials and provision of raw data to third parties since 2018 . Informed consent was obtained from all subjects.

\section{Consent for publication}

Not applicable.

\section{Competing of Interests}

All authors declare no potential conflict of interest.

\section{Author details}

${ }^{1}$ National Institute of Agricultural Sciences, 166 Nongsaengmyeong-ro Wanju-gun, Jeollabuk-do 55365, Korea. ${ }^{2}$ Major in Food Science, College of Biomedical and Health Science, Konkuk University, Chungju, Chungbuk 27478, Korea.

\section{References}

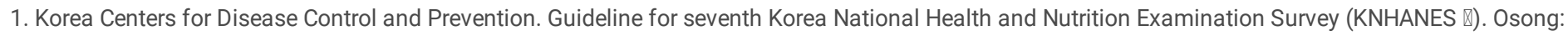
Korea Centers for Disease Control and Prevention; 2018.

2. Lichtenstein, AH.; Kennedy, E.; Barrier P, et al. Dietary fat consumption and health. Nutr Rev 1998; 56, S3-S28.

3. Hooper, L.; Summerbell, CD.; Higgins, JP.; et al. Dietary fat intake and prevention of cardiovascular disease: systematic review. BMJ 2001, $322,757-763$. 
4. Pot, GK.; Prynne, CJ.; Roberts, C.; Olson, A.; Nicholson, SK.; Whitton, C.; Teucher, B.; Bate,s B.; Henderson, H.; Pigott, S.; Swan, G.; Stephen, AM. National diet and nutrition survey: fat and fatty acid intake from the first year of the rolling programme and comparison with previous surveys. British $J$ Nutr 2012,107 , 405-41.

5. Jones, PJH.; Papamendjaris AA. Chapter 10 Lipids: cellular metabolism. In: Bowman BA, Russel RM, eds. Present Knowledge in ,Nutrition 8th ed. Washington D.C.: ILSI Press.; 2001. pp.104-114.

6. Choi H, Kim J, Kim Cl, Song GH, Jang GJ, Min HS, Lim KS, Byun GW, Song ES, Song JH, Kang SA, Yoe YJ, Lee HM, Kim KW, Kim H, Kim Cl, Nam KS, Yoon EY, Kim HA. Nutrition. Paju: Gyomoonsa; 2006. p69-112.

7. EFSA Panel on Dietetic Products, Nutrition, and Allergies(NDA). Scientific Opinion on Dietary Reference Values for fats, including saturated fatty acids, polyunsaturated fatty acids, monounsaturated fatty acids, trans fatty acids, and cholesterol. EFSA Journal 2010; 8(3),

8. Burlingame, B.; Nishida, C.; Uauy, R.; et al. Fats and fatty acids in human nutrition: introduction. Ann Nutr Metab 2009; 55, 5-7.

9. Institute of Medicine. Dietary Reference Intakes for Energy, Carbohydrate, Fiber, Fat, Fatty Acids, Cholesterol, Protein, and Amino Acids. Washington D.C.: National Academies Press; 2005. p422-588.

10. Song, SJ.; Shim, JE. Trends in dietary intake of total fat and fatty acids among Korean adolescents from 2007 to 2017. Nutrients 2019; 11(12),

11. Baek, Y.; Hwan,g JY.; Kim, K.; Moon, HK.; Kweon, S.; Yang, J.; Oh, K.; Shim, JE. Dietary intake of fats and fatty acids in the Korean population: Korea National Health and Nutrition Examination Survey, 2013. Nutr Res Pract 2015; 9, 650-657.

12. Song, SJ.; Shim, JE.; Song, WO. Trends in total fat and fatty acid intakes and chronic health conditions in Korean adults over 2007-2015. Public Health Nutr 2019; 22(8), 1341-1350.

13. Li, K.; McNulty, BA.; Tiernery AM, Devlin NF, Joyce T, Leite JC et al. Dietary fat intakes in Irish adults in 2011: how much has changed in 10 years? Br J Nutr 2016; 115(10), 1798-1809.

14. Joyce T, Wallace AJ, McCarthy SN and Gibney MJ. Intakes of total fat, saturated, monounsaturated and polyunsaturated fatty acids in Irish children, teenagers and adults. Public Health Nutr 2008; 12(2), 156-165.

15. Jayanama K, Theou O, Godin J, Cahill L. Association of fatty acid consumption with frailty and mortality among middle-aged and older adults. Nutrition $2020,70$.

16. De Souza RJ, Mente A, Maroleanu A, Cozma Al, Ha V, Kishibe T, Uleryk E, Budylowski P, Schünemann H, Beyene J, Anand SSI. Intake of saturated and trans unsaturated fatty acids and risk of all cause mortality, cardiovascular disease, and type 2 diabetes: systematic review and meta-analysis of observational studies. BMJ 2015; 351,

17. de Lorgeril M, Renaud S, Mamelle N, Salen P, Martin JL, Monjaud I. Mediterranean alpha-linolenic acid-rich diet in secondary prevention of coronary heart disease. Lancet 1994; 343(8911), 1454-9.

18. Dussaillant C, Echeverria G, Urquiaga I, Velasco N, Rigotti A. Current evidence on health benefits of the Mediterranean diet. Rev Med Chil 2016; 144(8), 1044-52.

19. Karam J, del Mar Bibiloni M, Pons A, Tur JA. Total fat and fatty acid intakes and food sources in Mediterranean older adults requires education to improve health. Nutr Res 2020; 73, 67-74.

20. Oh KW, Lee JM, Lee BS, Kweon SH, Lee YK, Kim YT. Plan and operation of the 4th korea national health and nutrition examination survey (KNHANES IV). Korean J Epidemiology. 2007; 29(2), 139-145.

21. Korea National Health and Nutrition Examination Survey. [Cited 2020 April 9]. Available from: https://knhanes.cdc.go.kr/knhanes/sub01/sub01_03.do

22. Song SJ, Shim JE. Evaluation of Total Fat and Fatty Acids Intakes in the Korean Adult Population using Data from the 2016-2017 Korea National Health and Nutrition Examination Surveys. Korean J Community Nutr 2019; 24(3), 223 231.

23. Korean Society for the Study of Obesity. Diagnosis and assessment of obesity [Internet]. Seoul: Korean Society for the Study of Obesity; [cited 2020 May 31]. Available from: http://general.kosso.or.kr/html/?pmode=obesityDiagnosis.

24. Chung SJ, Kang SH, Song SM, Ryu SH, Yoon J. Nutritional quality of Korean adults' consumption of lunch prepared at home, commercial places, and institutions: analysis of the data from the 2001 National Health and Nutrition Survey. Korean J Nutr 2006; 39(8), 841-849.

25. Shim JS, Oh K, Nam CM. Association of household food security with dietary intake - based on the third (2005) Korea National Health and Nutrition Examination Survey (KNHANES III). Korean J Nutr 2008; 41(2), 174-183.

26. Lee S, Lee KW, Oh JE, Cho MS. Nutritional and health consequences are associated with food insecurity among Korean elderly: Based on the fifth (2010) Korea National Health and Nutrition Examination Survey (KNHANES V-1). J Nutr Health 2015; 48(6), 519-529.

27. Ministry of Health and Welfare, The Korean Nutrition Society, Dietary reference intakes for Koreans 2015, Sejong; 2015.

28. Schlundt DG, Hill JO, Sbrocco T, Pope-Cordle J, Sharp T. The role of breakfast in the treatment of obesity: a randomized clinical trial. Am J Clin Nutr 1992; 55(3), 645-651.

29. Alexander KE, Ventura EE, Spruijt-Metz D, Weigensberg MJ, Goran MI, Davis JN. Association of breakfast skipping with visceral fat and insulin indices in overweight Latino youth. Obesity (Silver Spring) 2009; 17(8), 1528-1533.

30. Sakata K, Matumura Y, Yoshimura N, Tamaki J, Hashimoto T, Oguri S, Okayama A, Yanagawa H. Relationship between skipping breakfast and cardiovascular disease risk factors in the national nutrition survey data. Nihon Koshu Eisei Zasshi 2001; 48(10), 837-841.

31. Jang SH, Suh YS, Chung YJ. Metabolic risk and nutritional state according to breakfast energy level of Korean adults: Using the 2007 2009 Korea National Health and Nutrition Examination Survey J Nutr Health 2015; 48(1), 46-57. 
32. Kwon YS, Ju SY. Trends in nutrient intakes and consumption while eating-out among Korean adults based on Korea National Health and Nutrition Examination Survey (1998-2012) data. Nutr Res Pract, 2014; 8, 670-678.

33. Choi I, Kim WG, Yoon J. Energy intake from commercially-prepared meals by food source in Korean adults: Analysis of the 2001 and 2011 Korea National Health and Nutrition Examination Surveys. Nutr Res Pract 2017;11(2):155-163.

34. Kant AK, Whitley MI, Graubard BI. Away from home meals: Associations with biomarkers of chronic disease and dietary intake in American adults, NHANES 2005- 2010. Int J Obes (Lond) 2015; 39(5), 820-827

35. Ju Changes in Eating-Out Frequency according to Sociodemographic Characteristics and Nutrient Intakes among Korean Adults. Iran J Public Health, 2020; 49(1), 46-55.

36. Rual Development Administration. Korean food composition table. 8th ed. 2011. Suwon; Korea p.84-426.

37. Eckel RH, Jakicic JM, Ard JD, de Jesus JM, Houston Miller N, Hubbard VS, Lee IM, Lichtenstein AH, Loria CM, Millen BE, Nonas CA, Sacks FM, Smith SC Jr, Svetkey LP, Wadden TA, Yanovski SZ, Kendall KA, Morgan LC, Trisolini MG, Velasco G, Wnek J, Anderson JL, Halperin JL, Albert NM, Bozkurt B, Brindis RG, Curtis LH, DeMets D, Hochman JS, Kovacs RJ, Ohman EM, Pressler SJ, Sellke FW, Shen WK, Smith SC Jr, Tomaselli GF. American College of Cardiology/American Heart Association Task Force on Practice Guidelines. 2013 AHA/ACC guideline on lifestyle management to reduce cardiovascular risk: a report of the American College of Cardiology/American Heart Association Task Force on Practice Guidelines. Circulation, 2014; 129(25 Suppl 2), S76-99.

38. Ordovas JM, Corella D, Demissie S, Cupples LA, Couture P, Coltell O, Wilson PW, Schaefer EJ, Tucker Dietary fat intake determines the effect of a common polymorphism in the hepatic lipase gene promoter on high-density lipoprotein metabolism: evidence of a strong dose effect in this gene-nutrient interaction in the Framingham Study. Circulation 2020; 106, 2315-2321.

39. Salopuro T. Studies on selected human obesity candidate genes: Doctoral dissertation of Clinical Nurition \& Food Health Research Center. D. Thesis, Kuopio University, Finland, 2009.

40. Li Y, Hruby A, Bernstein AM, Ley SH, Wang DD, Chiuve SE et al. Saturated fats compared with unsaturated fats and sources of carbohydrates in relation to risk of coronary heart disease: a prospective cohort study. J Am Coll Cardiol 2015; 66(14), 1538-1548.

41. Welsh JA, Sharma A, Abramson JL, Vaccarino V, Gillespie C, Vos MB. Caloric sweetener consumption and dyslipidemia among US adults. JAMA 2010; 303(15), 1490-1497.

42. Anderson JW, Randles KM, Kendall CW, Jenkins DJ. Carbohydrate and fiber recommendations for individuals with diabetes: a quantitative assessment and meta-analysis of the evidence. J Am Coll Nutr 2004; 23(1), 5-17.

43. The Homepage of Korea National Health and Nutrition Examination Survey. Available online: https://knhanes.cdc.go.kr/knhanes/sub05/sub05_01_view.do (accessed on 21 September 2020).

44. Zhilei S, Yanjun Guo, Frank BH, Liegang L, Qibin Q. Association of low-carbohydrate and low-fat diets with mortality among US adults. JAMA Intern Med. 2020; 180(4), 513-523.

\section{Figures}




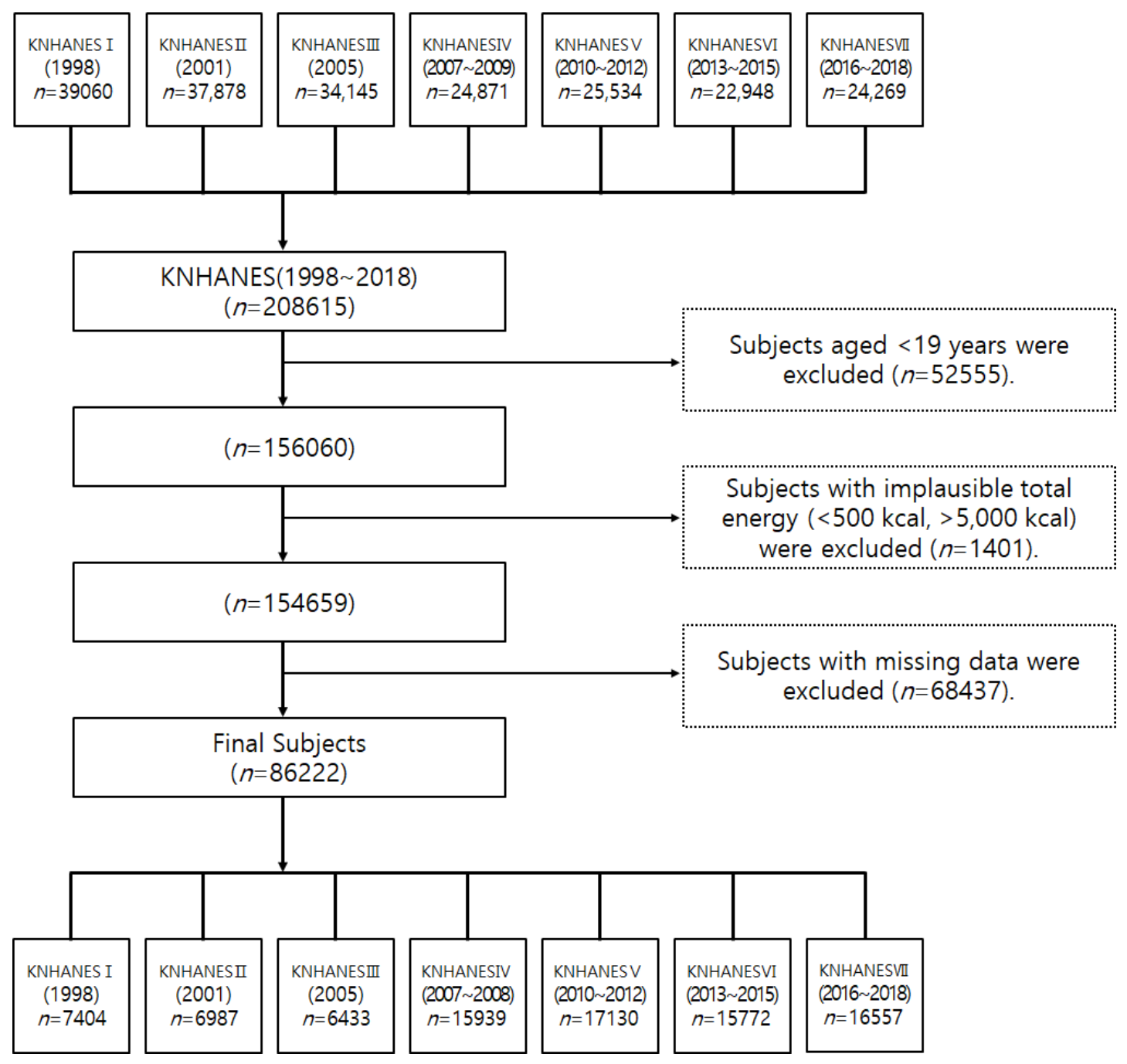

Figure 1

Flow chart for subject sample of this study 


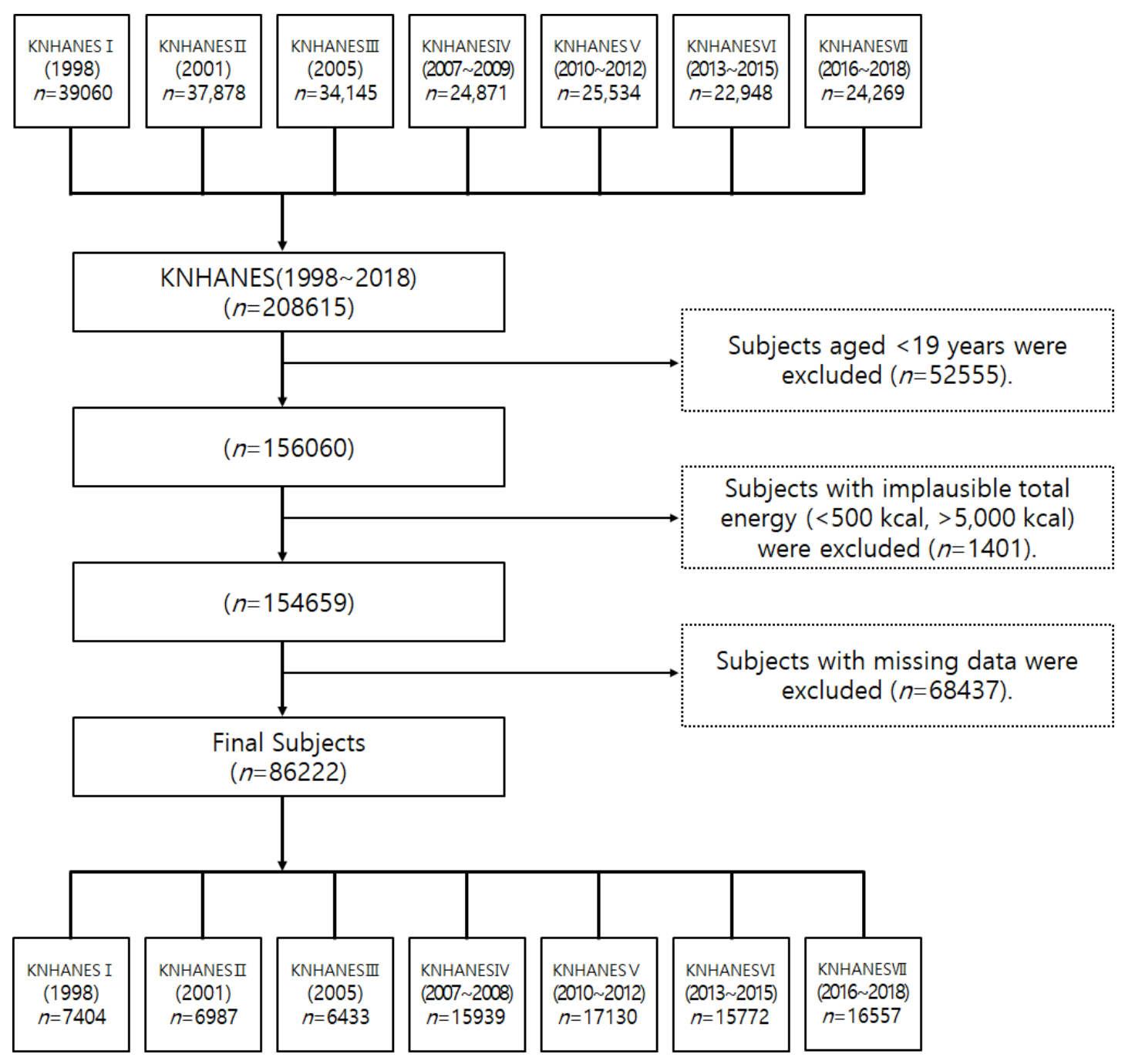

Figure 1

Flow chart for subject sample of this study 

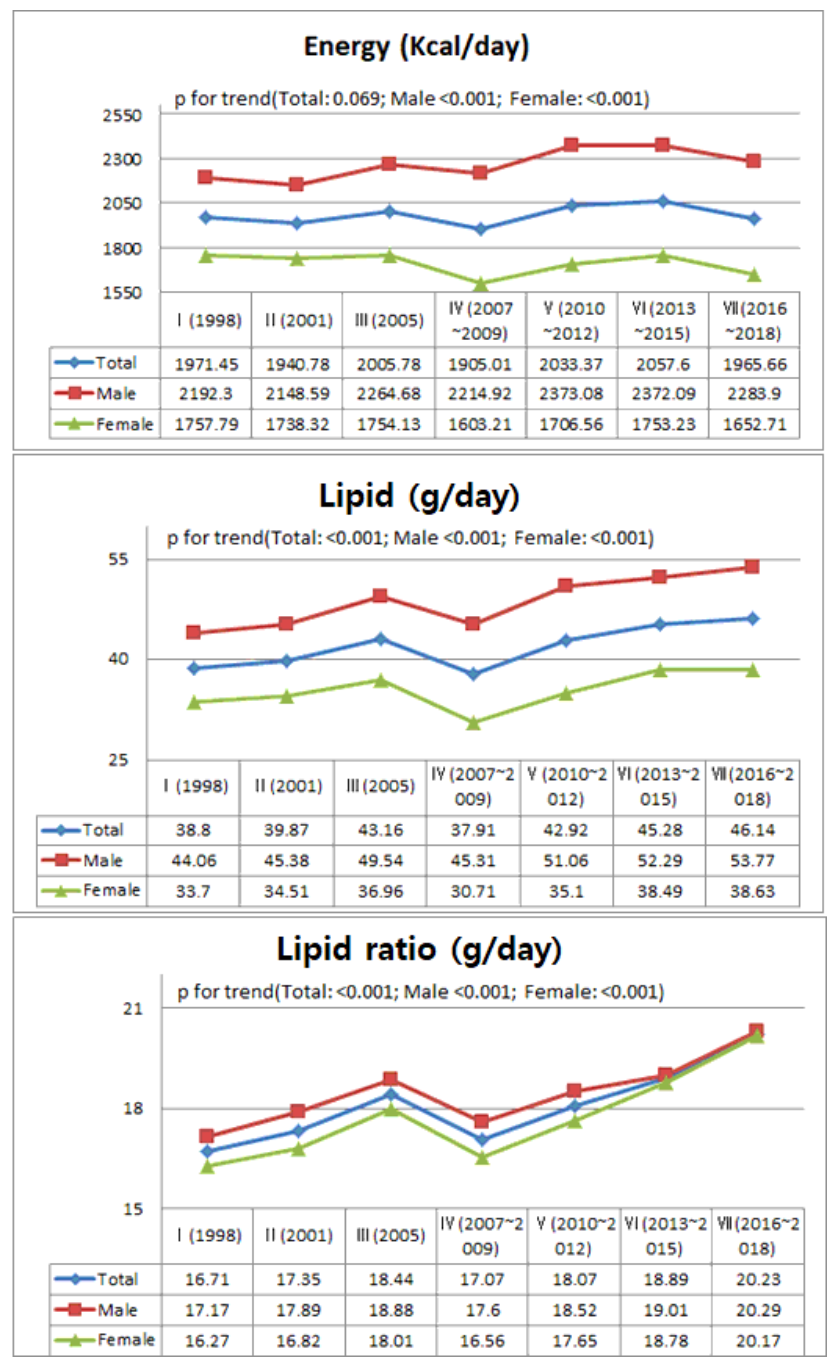

\section{Figure 2}

Trend of Lipid intake according to year of Korean adultsa a All p for trend were calculated by surveyreg procedure of SAS. 

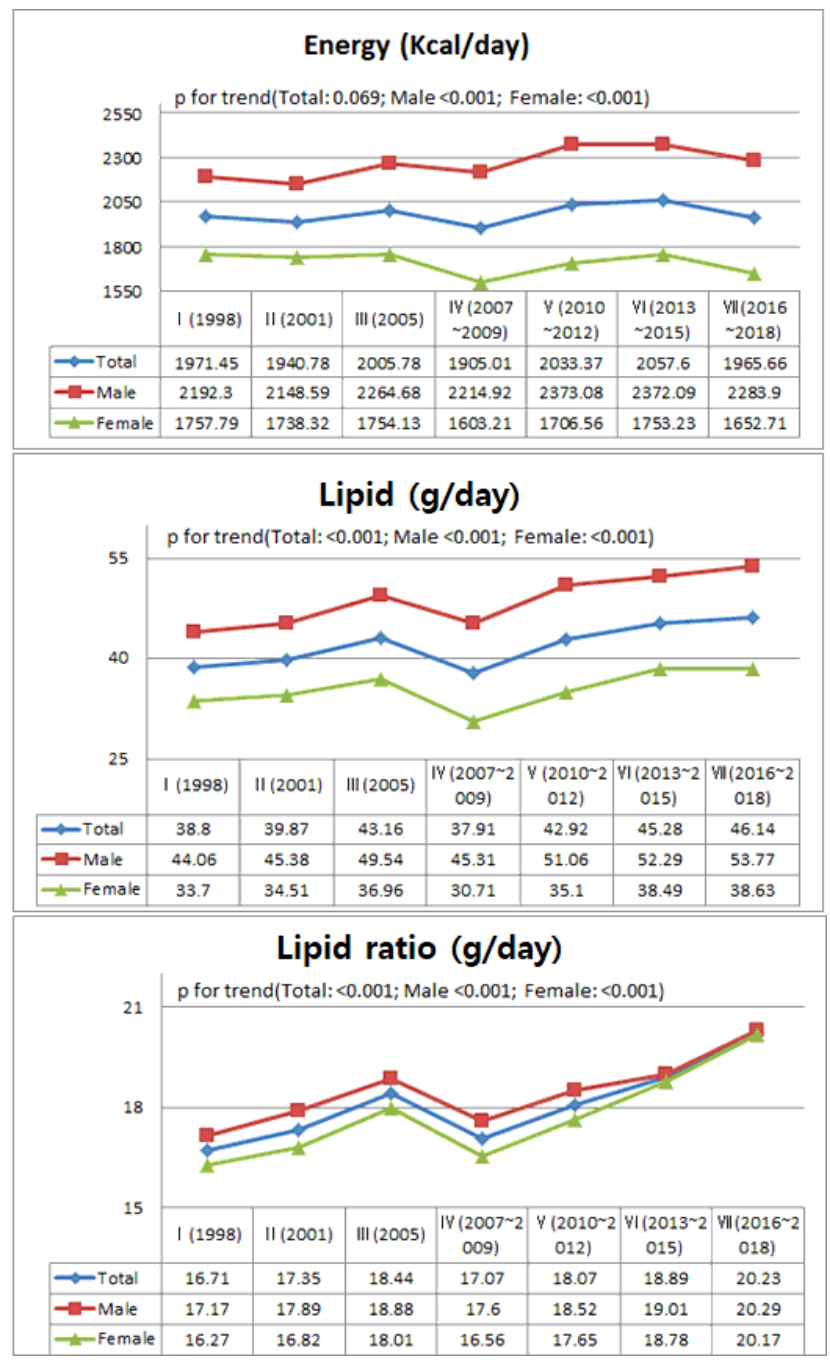

\section{Figure 2}

Trend of Lipid intake according to year of Korean adultsa a All p for trend were calculated by surveyreg procedure of SAS.

\section{Supplementary Files}

This is a list of supplementary files associated with this preprint. Click to download.

- Suppltable.docx

- Suppltable.docx 